Kannan, D., Sousa Jabbour, A. B. L., \& Jabbour, C. J. C. (2014). Selecting green suppliers based on GSCM practices: Using fuzzy TOPSIS applied to a Brazilian electronics company. European Journal of Operational Research, 233(2), 432-447.

https://doi.org/10.1016/j.ejor.2013.07.023 
Selecting green suppliers based on GSCM practices: Using Fuzzy TOPSIS applied to a Brazilian electronics company

\section{Devika Kannan (AUTHOR FOR CONTACT)}

Department of Mechanical and Manufacturing Engineering

Aalborg University, Copenhagen, Denmark.

\section{Ana Beatriz Lopes de Sousa Jabbour}

UNESP - Univ Estadual Paulista

Address: Av. Eng. Edmundo Carrijo Coube, 14-01, Bauru, Sao Paulo, Brazil

\section{Charbel José Chiappetta Jabbour}

UNESP - Univ Estadual Paulista

Address: Av. Eng. Edmundo Carrijo Coube, 14-01, Bauru, Sao Paulo, Brazil

Corresponding author

E-mail: mdevi89@rediffmail.com 


\title{
Selecting green suppliers based on GSCM practices: Using Fuzzy TOPSIS applied to a Brazilian electronics company
}

\begin{abstract}
Due to an increased awareness and significant environmental pressures from various stakeholders, companies have begun to realize the significance of incorporating green practices into their daily activities. This paper proposes a framework using Fuzzy TOPSIS to select green suppliers for a Brazilian electronics company; our framework is built on the criteria of green supply chain management (GSCM) practices. An empirical analysis is made, and the data are collected from a set of 12 available suppliers. We use a fuzzy TOPSIS approach to rank the suppliers, and the results of the proposed framework are compared with the ranks obtained by both the geometric mean and the graded mean methods of fuzzy TOPSIS methodology. Then a Spearman rank correlation coefficient is used to find the statistical difference between the ranks obtained by the three methods. Finally, a sensitivity analysis has been performed to examine the influence of the preferences given by the decision makers for the chosen GSCM practices on the selection of green suppliers. Results indicate that the four dominant criteria are Commitment of senior management to GSCM; Product designs that reduce, reuse, recycle, or reclaim materials, components, or energy; Compliance with legal environmental requirements and auditing programs; and Product designs that avoid or reduce toxic or hazardous material use.
\end{abstract}

Keywords: Green supply chain management (GSCM); Green supplier selection; fuzzy set theory; TOPSIS; triangular fuzzy number.

\section{Introduction}

Environmental issues are no longer a concern only for environmental experts; environmental awareness affects almost all parts of our society and it is a special concern for our industrial sectors (Sarkis, 1998; Hart and Dornell, 2011). Companies and their decision makers must consider environmental issues in all of their administrative activities (Marcus and Fremeth, 2009), including the role of the supply chain (Linton et al., 2007) and the firms' selection of suppliers (Genovese et al., 2013). One of the most important and difficult decisions in supplier selection process is the commitment to environmental causes (Dekker et al., 2012). Thus, the process for supplier selection creates a new research area known as green supplier selection, and this area has many research gaps still to be explored (Kumar et al., 2014). Green supplier selection should be considered important when companies are looking for greener supply chain management, including, for example, remanufacturing targets (Xiong et al., 2013).

Several environmental criteria may be emphasized when selecting the most environmentally friendly suppliers (Dekker et al., 2012). For example, several studies have suggested that the supplier selection can be based on the criteria related to environmental practices (Humphreys et al., 2003) or to hazardous material management (Hsu and $\mathrm{Hu}, 2009$ ). Other studies address social, economic, and environmental sustainability practices as the criteria for the supplier selection (Govindan et al., 2013) in the context of more sustainable supply chains (Seuring, 2013). However, 
the best manner by which a firm might select suppliers based on their GSCM reputation is still a missing link in the literature.

Hence, studies that propose supplier selection based on the supplier's adoption of Green Supply Chain Management (GSCM) practices, a modern environmental sustainability concept, are still to be done. GSCM offers an expanded perspective on environmental management that considers practices adopted both inside and outside the company (Ageron et al., 2012), and this approach can generate more business opportunities for firms (Wang and Chan, 2013). In addition, although studies on supplier selection based on environmental criteria in many national contexts are available (Baskaran et al. 2012; Large and Thomsen, 2011), proposals that consider the realities of the developing countries -- mainly the BRICs countries -- are still scarce and deserve more attention from researchers. For example, in 2010, Brazil formulated new environmental legislation called the National Solid Waste Policy. This new legislation requires firms and municipalities to adopt proactive green management values and practices, and companies are feeling pressured to enact these environmentally sensitive practices in a timely manner (Jabbour et al., 2013a).

Suppliers that adopt GSCM practices may encourage improved environmental performance throughout the entire supply chain (Genovese et al., 2013; Kumar et al., 2014). Advances in creating novel supplier selection approaches as part of applying GSCM may help companies to address continuing challenges in the green supplier selection process and thus to improve their environmental performance (Handfield et al., 2002). Clearly, a company's environmental management performance level is highly correlated with its adoption of green supplier selection practices (Jabbour and Jabbour, 2009). In this context, many quantitative approaches have been proposed to facilitate the green supplier selection process more efficiently. For example, researchers have proposed the application of Green Data Envelopment Analysis (Kumar et al., 2014), hierarchical fuzzy TOPSIS approach (Wang and Chan, 2013), and other methodologies, such as Life Cycle Assessment, Multi-criteria Decision Making, and Analytical Hierarchy Process (Seuring, 2013).

No current research discusses how companies might use GSCM practices as criteria by which to select green suppliers. Within this context, a primary concern of the present study is to explore how a company can select green suppliers who employ GSCM practices based on a fuzzy approach. The aim of the article is to select the green suppliers based on the GSCM practices using the fuzzy TOPSIS approach. Additionally, this research discusses the case of a Brazilian company operating in an electronic sector. Brazil is an emerging country which belongs to the BRICS group; Brazil is also responsible for about 35\% of all the Latin America GDP (Jabbour and Jabbour, 2013), which certainly attracts the attention of many international economic players. Further, systematic searches -- using the words "green supply chain," "supplier selection," "green," "environmental," or "green practices" -- conducted in the ISI Web of Knowledge database during 2012 and 2013 showed no similar research to this proposal.

\section{Literature review}

\subsection{Green supply chain management}

Green supply chain management is not a concept on which all researchers agree (Ahi and Searcy, 2013). However, the majority of authors state that it emerges from the ideas that companies must become greener (Marcus and Fremeth, 2009), must try to reach a win-win perspective (Hart and 
Dowler, 2011) and must link the supply chains and sustainable development (Seuring, 2013). The concepts of GSCM emerged from the realization that isolated implementations of environmental practices by companies are not as effective as collective actions that make the entire supply chain greener (Ageron et al., 2012). This broader systematic perspective of environmental management dispersed among all players in a supply chain has been called GSCM (Linton et al., 2007). This concept is a part of the broad effort to align operations management with the goal of improving the quality of life in society (Sarkis, 2012) and it is a theme that requires more attention and emphasis in future studies (Gunasekaran and Gallear, 2012).

GSCM is, therefore, a part of the environmental dimension of the Sustainable Supply Chain Management (SSCM) concept (Seuring and Müller, 2008). SSCM can be defined as the management of materials, the distribution of information, the flow of capital, and cooperation among companies in a supply chain as they strive to improve their economic, environmental, and social performances while simultaneously considering the expectations of other stakeholders (Seuring and Müller, 2008). The interest of the scientific community in this subject is increasing quickly (Seuring, 2013). A summary of the state-of-the art, most influential works on GSCM can be found in Table 1a. Using the keywords "green supply chain," "green supply chain management," and "environmental supply chain management," a search in the ISI Web of Knowledge database produced the ten most cited works in this field of knowledge; they are depicted in Table 1a.

$* * * * * * * * *$ Table 1 a about here $* * * * * * * * *$

From this literature review, several definitions of GSCM deserve attention:

- GSCM encompasses a set of environmental practices that encourage improvements to the environmental practices of two or more organizations within the same supply chain (Vachon and Klassen, 2006);

- GSCM is the process of incorporating environmental concerns into supply chain management including product design, material sourcing and selection, manufacturing, delivery of final products, and the management of product's end-of-life (Srivastava, 2007);

- GSCM can be achieved by considering environmental issues at the purchasing, product design and development, production, transportation, packaging, storage, disposal, and end of product life cycle management stages (Min and Kin, 2012);

- GSCM is the integration of environmental concerns in the inter-organizational practices of supply chain management (Sarkis et al., 2011).

Companies can apply GSCM as a group of practices, as shown in Table 1b. In this research, we included 17 (Table 1b) of the 21 practices statistically confirmed by Zhu et al. (2008). The reduced number of GSCM practices was justified by the following considerations: (a) some practices were redundant, and excluding them reduces the number of variables in the study, and (b) practices with similar approaches are grouped together. Thus, we excluded the overlapping of some GSCM practices, namely: environmental management systems (because ISO14001 has been considered as a GSCM practice); TQEM (because it is not a clear approach to Brazilian companies); support of the middle-manager (because there is a GSCM practice entitled "top management commitment"); and green label (because there is a GSCM practice regarding the green criteria for selection 
suppliers). These four practices have not been considered from the set of GSCM practices considered in this research.

\section{$* * * * * * * * *$ Table $1 \mathrm{~b}$ about here $* * * * * * * * *$}

Some recent findings confirm the relevance of GSCM for companies' success. For example, Diabat et al. (2013) found the three most relevant GSCM practices of the automotive industry in a developing country are design for environment, collaboration with clients, and reverse logistics. Based on a survey with 163 container shipping firms in Taiwan, Yang et al. (2013) determined that internal green practices and external green collaboration have positive impacts on green performance, and as a result, a firm's competitveness based on GSCM practices is enhanced. GSCM is particularly relevant in contemporary organizational management because it can create synergy with other managerial principles such as lean manufacturing (Dües et al., 2013).

However, not all companies adopt GSCM practices equally (Lai and Wong, 2013). For example, Ageron et al. (2012) conducted a study of more than 170 French companies to analyze the degree to which environmental sustainability in supply chain management may have been included. They discovered that: (a) strategic plans and actions are fundamental to the adoption of green supply chain management; (b) the size of the company and its international activities may influence its participation in a green supply chain; and (c) waste management is a central theme of these companies. In developing countries, GSCM may not be considered a realistic option for most firms (Diabat et al., 2013). In Brazil, for example, the internationalization of firms has positively motivated the adoption of GSCM practices, but at the national level, this process is still in the implementation stage for many companies (Jabbour et al., 2013b). For Brazil, the adoption of GSCM should be implemented to advance the production and marketing acceptance of environmentally-improved products (Tomasin da Silva et al., 2013).

\subsection{Green supplier selection}

The increased inclusion of environmental considerations in the fields of operations management and supply chains has become a strong trend (Gunasekaran and Ngai, 2012). One of the most important GSCM practices is to choose environmental considerations in supplier selection, maintenance, and development (Dekker et al., 2012). For Kumar et al. (2014) the supplier selection process involves a set of activities such as identifying, analyzing, and choosing suppliers to become a tier of the supply chain. Suppliers who adopt GSCM practices can strengthen the environmental performances of companies throughout the supply chain. Addressing the environmental criteria during supplier selection process is even more important in developing countries because of the difficulties and barriers companies in these countries face (Akamp and Müller, 2011).

Supplier selection based on environmental criteria has attracted the attention of many investigators. In 2012, a search for papers about this topic were conducted. As a result, a summary of the ten most cited articles in the ISI Web of Science journal have been selected and listed in table 1c. It is important to note that thsee papers were selected only from the journals and not from the proceedings.

\section{$* * * * * * * * *$ Table 1c about here $* * * * * * * * *$}

There are many others studies that discuss green supplier selection. For example, Large and Thomsen (2011) utilized data from more than 100 German companies and discovered that the degree of green supplier assessment and the level of green collaboration directly influence a 
company's environmental performance. These two practices are driven at the strategic level by the purchasing department and through the firm's level of environmental commitment. Other researchers have consistently indicated that including environmental considerations in supplier selection is a fundamental practice among organizations that strive for sustainability (Sarkis, 1998; Dekker, 2012).

However, although there is a consensus that supplier selection using environmental criteria is important, some challenges exist in developing robust selection methods (Humphreys et al., 2003). Accordingly, several studies have proposed a variety of approaches to overcome these challenges.

A study by Baskaran et al. (2012) analyzed the inclusion of socio-environmental sustainability criteria in the Indian textile industry. This study indicated that the criterion of long working hours plays an important role in evaluating suppliers of garment manufacturers and ancillary suppliers. The study also found that pollution and unfair competition were important criteria when evaluating the garment manufacturers. Employing child labor was found to be a critical criterion when evaluating the ancillary suppliers.

Govindan et al. (2013) explored sustainable supply chain initiatives and presented a fuzzy multi-criteria approach to identify an effective model for supplier selection in supply chains based on the triple bottom line (TBL) approach (i.e., economic, environmental, and social considerations).

Hsu and $\mathrm{Hu}$ (2009) presented an Analytic Network Process (ANP) approach to incorporate the issue of Hazardous Substance Management (HSM) into the supplier selection. An illustrative example in an electronics company was presented to demonstrate how to select the most appropriate supplier in accordance with environmental regulatory requirements on hazardous substances.

However, environmental evaluation of the GSCM practices that suppliers could adopt is lacking. Suppliers who adopt GSCM practices may encourage improved environmental performance throughout the entire supply chain. Advances in the development of novel GSCM approaches for selecting suppliers may help companies that still struggle with green supplier selection (Handfield et al., 2002).

\subsection{Fuzzy TOPSIS}

The TOPSIS approach is a widely accepted method used for ranking problems in real time situations. The major limitation of the TOPSIS method lies in the inability to capture the vagueness or ambiguity inherent in the decision making process (Yu, 2002). In order to overcome this limitation, the fuzzy set theory can be used with the traditional TOPSIS approach to allow decisionmakers to incorporate unquantifiable information, incomplete information, non-obtainable information, and partially ignorant facts into the decision model (Deviren et al., 2009; Kulak et al., 2005). Hence, the fuzzy TOPSIS approach should be more appropriate and effective than conventional TOPSIS (Gumus, 2009), and fuzzy TOPSIS can be successfully used in the various application areas of MCDM problems (Table 1d).

\section{$* * * * * * * * *$ Table 1d about here $* * * * * * * * *$}

\section{Problem description}

A Brazilian electronics industry (company $\mathrm{A}^{1}$ ) is chosen for this study. Company $\mathrm{A}$ has approximately 4,000 employees per shift; they assemble electronics products such as notebooks,

\footnotetext{
${ }^{1}$ To maintain confidentiality, the company's name is designated as company A.
} 
tablets, and desktop computers. The company is one of the leaders in its product segment in Brazil; its main customers are major national retailers and the government.

This company has enacted changes in the structure of the final product in order to make it lighter, free of harmful chemicals, recyclable, and to lower its electricity consumption. These changes, in turn, meet both environmental legislation regulations and the demands of their customers. The company has also dedicated itself to an analysis of the life cycle assessment (LCA) of the product. LCA conducts an inventory of emissions, consumption of raw materials, and waste generation, and this inventory allows the company to evaluate its own usage of such resources and to implement reduction practices.

In Brazil, according to the 2010 National Policy on Solid Waste, all companies in the electronics sector are now required to take responsibility for their post-consumer products take-back and environmental impacts. Because of the Brazilian government's mandate, companies recognize that offering greener electronics products not only meets customer demand but also requires locating good green suppliers to improve their supply chain management.

Because of this new context in Brazil, the company's sustainability manager seeks a way to identify and to select suppliers who will support the company's adoption of GSCM practices. 12 major suppliers have been identified as candidates for company A. With this company's objectives in mind, the authors of this paper prepared a survey questionnaire (based on section 2.1) and submitted it for content analysis to four academic experts. Then, we asked the opinion of three experts who work with the marketing context of GSCM in order to check their preferences when using GSCM practices to select suppliers. Figure 1 shows the framework of this research and the five-phase methodology adopted in this work.

\section{Development of solution methodology}

In this work, we have adopted a fuzzy TOPSIS methodology for solving the multi criteria decision making problem of green supplier selection for a Brazilian electronics company. This section briefly describes the fuzzy sets and linguistic variables, the TOPSIS method, and the proposed fuzzy TOPSIS method.

\subsection{Fuzzy set theory}

In several situations, crisp numbered data are insufficient to model real world systems due to the vagueness, imprecision, and subjective nature of human thinking, judgment, and preferences (Olfat et al, 2012). Also, because in various situations, performance ratings and weights cannot be given precisely, fuzzy set theory is introduced to model the uncertainty of human judgments; the process is called fuzzy multi criteria decision making (FMCDM) (Singh and Benyoucef, 2011). Zadeh $(1965,1976)$ introduced the fuzzy set theory in multi criteria decision making (MCDM) to resolve the uncertainty and vagueness of human cognitive and judgment by providing mathematical strengths to work out such uncertainties of human thinking and reasoning. Use of fuzzy sets to analysis the decision-making problem was first introduced by Bellman and Zadeh (1970) (Olfat et al., 2012). Fuzzy set theory, an extension of the crisp set theory, uses linguistic terms to represent the decision maker's selections. In FMCDM problems, the ratings and weights of the attributes estimated on vagueness, imprecision, and subjectivity are expressed in linguistic terms and then converted to fuzzy numbers (Kannan et al., 2009). In this paper, fuzzy set theory is used to model 
the green supplier selection for a Brazilian electronics industry, and triangular fuzzy numbers (TFN) are used to review the decision maker's preference because it captures the vagueness of the linguistic assessments and thereby contributes to the easy usage and computational simplicity (Kannan et al., 2009). From the literature it is proved that TFN is an effective way of formulating decision problems containing subjective and imprecise information (Torlak et al., 2011; Deviren, 2009; Chang and Yeh, 2002; Chang et al., 2007; Kahraman et al., 2004; Zimmerman, 1996). A triangular fuzzy number is defined as $(a, b, c)$, where $a \leq b \leq c$. The parameters $a, b$, and c indicate the smallest possible value, the middle possible value, and the largest possible value, respectively that describe a fuzzy event. Some important definitions and notations of fuzzy set theory used in this article are as follows (Zadeh, 1965, 1976; Zimmerman, 1996; Awasthi et al., 2011; Kannan et al., 2012; Olfat et al., 2012; Singh \& Benyoucef, 2011):

Definition 1: (Fuzzy set)

Let $\mathrm{X}$ be the universe of discourse, $X=\left\{x_{1}, x_{2}, \ldots, x_{n}\right\}$. A fuzzy set $A$ of $\mathrm{X}$ is a set of order pairs $\left\{\left(x_{1}, f_{A}\left(x_{1}\right)\right),\left(x_{2}, f_{A}\left(x_{2}\right)\right), \ldots,\left(x_{n}, f_{A}\left(x_{n}\right)\right)\right\}$, where $f_{A}: X \rightarrow[0,1]$ is the membership function of $A$, and $f_{A}\left(x_{i}\right)$ stands for the membership degree of $x_{i}$ in $A$.

Definition 2: (Fuzzy number)

A triangular fuzzy number can be expressed as a triplet (a, b, c); the membership function of the fuzzy number $f_{A}(x)$ is illustrated in Fig. 2 and defined as:

$f_{A}(x)= \begin{cases}0 & x<a_{x} x>c \\ \frac{w-a}{b-a^{v}} & a \leq x \leq b \\ \frac{a-w^{3}}{a-b}, & b \leq x \leq c\end{cases}$

$* * * * * * * * *$ Figure 2 about here $* * * * * * * * *$

Due to their conceptual and computational simplicity, triangular fuzzy numbers are more commonly used in practical applications (Awasthi et al., 2011; Singh \& Benyoucef, 2011).

\section{Definition 3:}

Assume that $\mathrm{A}=(\mathrm{a}, \mathrm{b}, \mathrm{c})$ and $\mathrm{B}=\left(\mathrm{a}_{1}, b_{1}, c_{1}\right)$ are real numbers, then the distance measurement $\mathrm{d}\left(\mathrm{a}_{1} \mathrm{a}_{2}\right)$ , is identical to the Euclidean distance (Chen, 2000).

\section{Definition 4:}

Let $A=(a, b, c)$ and $B=\left(a_{1}, b_{1}, c_{1}\right)$ be two triangular fuzzy numbers. Then the operational laws of these two triangular fuzzy numbers are as follows:
$\mathrm{A}(+) \mathrm{B}=(a, b, c)(+)\left(a_{1}, b_{1}, c_{1}\right)=\left(a+a_{1}, b+b_{1}, \mathrm{c}+c_{1}\right)$
$\mathrm{A}(-) \mathrm{B}=(a, b, c)(-)\left(a_{1}, b_{1}, c_{1}\right)=\left(a-c_{1}, b-b_{1}, c-a_{1}\right)$
$\mathrm{A}(\times) \mathrm{B}=(a, b, c)(\times)\left(a_{1}, b_{1}, c_{1}\right)=\left(a a_{1}, b b_{1}, c c_{1}\right)$
$\mathrm{A}(\div) \mathrm{B}=(a, b, c)(\div)\left(a_{1}, b_{1}, c_{1}\right)=\left(\frac{\mathrm{a}}{\mathrm{c}_{1}}, \frac{\mathrm{b}}{b_{1}}, \frac{\mathrm{c}}{\mathrm{a}_{1}}\right)$
$\mathrm{kA}=(\mathrm{ka}, \mathrm{kb}, \mathrm{kc})$
$(A)^{-1}=(1 / c, 1 / b, 1 / a)$

\section{Definition 5:}

Let $A=(a, b, c)$ and $B=\left(a_{1}, b_{1}, c_{1}\right)$ be two triangular fuzzy numbers (Fig. 3). The distance between the two fuzzy numbers is calculated using the vertex method and the same is given by

$\mathrm{d}(\mathrm{A}, \mathrm{B})=\sqrt{1 / 3\left[\left(a-a_{1}\right)^{2}+\left(b-b_{1}\right)^{2}+\left(c-c_{1}\right)^{2}\right]}$ 


\section{Definition 6:}

Assume that a decision making committee consists of $\mathrm{K}$ decision makers, and the fuzzy rating of each decision maker $D_{k}(\mathrm{k}=1,2, . ., \mathrm{K})$ can be represented as a positive triangular fuzzy number $R_{k}(\mathrm{k}=1,2, \ldots, \mathrm{K})$ with membership function $F_{R_{k}}(\mathrm{x})$. Then the aggregated fuzzy rating can be defined as:

$\mathrm{R}=(\mathrm{a}, \mathrm{b}, \mathrm{c}), \mathrm{k}=1,2, . ., \mathrm{K}$

Where $a=\min _{k}\left\{a_{k}\right\}, \mathrm{b}=1 / \sum_{k} \sum_{k=1}^{K} b_{k}, c=\max _{k}\left\{c_{k}\right\}$

\section{Linguistic variable:}

A linguistic variable is a variable whose values are words or sentences of a natural or artificial language that are expressed in linguistic terms which are then represented by the triangular fuzzy number. Usually, conversion scales are used to transform linguistic terms into fuzzy numbers (Torlak et al., 2011; Singh and Benyoucef, 2011, Awasthi et al., 2011). In this research work, we use $0-1$ scale and 0-10 scale to rate the criteria and alternatives respectively. The linguistic variables and fuzzy ratings used for the alternatives and criteria are presented in table 2 and table 3, respectively, and the same is shown below.

$* * * * * * * * *$ Table 2 \& 3 about here $* * * * * * * * *$

\subsection{Fuzzy TOPSIS}

Hwang and Yoon (1981) proposed a technique for order preference by similarity to ideal solution which is known as TOPSIS (Yu et al., 2012).This technique is one of the classical methods for solving the MCDM problems (Olfat et al., 2012). The vital idea of the TOPSIS is to define the positive and negative ideal solutions and then to measure the distance of the alternatives from the ideal solutions based on which the rankings of the alternatives are determined. The positive ideal solution (PIS) is the solution which maximizes the benefit criteria and minimizes the cost criteria, whereas the negative ideal solution (NIS) maximizes the cost criteria and minimizes the benefit criteria. The selected alternative should be closest to the PIS and farthest away from NIS. TOPSIS identifies an index called closeness coefficient (similarity) to the PIS and remoteness to the NIS. Finally, the method selects an alternative whose closeness coefficient to the PIS is maximum (Kahraman et al., 2009; Torlak et al., 2011). In fuzzy TOPSIS, the ratings and the weights are defined by the linguistic variable which is then set to fuzzy numbers called TFN.

The fuzzy TOSIS method, according to Hwang and Yoon (1981) and Kannan et al., (2009), is summarized as follows:

\section{Step 1: Constructing the decision matrix}

Let us consider a group of $k$ decision makers $\left(D_{1}, D_{2} \ldots \ldots . D_{k}\right)$ containing $m$ alternatives $\left(A_{1}\right.$, $\left.A_{2} \ldots \ldots . A_{m}\right)$ and $n$ criteria $\left(C_{1}, C_{2} \ldots \ldots C_{n}\right)$ for a MCDM problem which is clearly expressed in a matrix format as: 


$$
D=\begin{gathered}
C_{1} \\
A_{1} \\
A_{2} \\
\vdots \\
A_{m}
\end{gathered}\left[\begin{array}{cccc}
r_{11} & r_{12} & \cdots & r_{1 n} \\
r_{21} & r_{22} & \cdots & r_{2 n} \\
\vdots & \vdots & \cdots & \vdots \\
r_{m 1} & r_{m 2} & \cdots & r_{m n}
\end{array}\right]
$$

Where, $r_{m n}$ be the rating of alternative $A_{m}$ with respect to criterion $C_{n}$. Let $W_{j}=\left(W_{1}, W_{2} \ldots \ldots W_{n}\right)$ be the relative weight vector of the $n$ criteria that should be equal to 1 .

\section{Step 2: Aggregate the evaluation of decision makers}

In this step, the decision makers' aggregate evaluations for determining the criteria weights and aggregate rating of alternatives are performed as follows:

\section{Aggregate the criteria weights}

Let $w_{j t}=\left(a_{j t}, b_{j t}, c_{j t}\right), j=1,2, \ldots, n, t=1,2, \ldots, k$ be the weight assigned by the decisionmaker $D_{k}$ to criterion $C_{j}$. First, the fuzzy number $w_{j t}=\left(a_{j t}, b_{j t}, c_{j t}\right)$ is converted into a crisp number $w^{\prime}{ }_{j t}$ using graded mean integration method (Kannan et al., 2009). Then, the aggregated importance weight $W_{j}$ of criterion $C_{j}$ assessed by the committee of $k$ decision-makers can be evaluated as:

$$
W_{j}=\frac{\sum_{t=1}^{k} w_{j t}^{\prime}}{k}
$$

where $w^{\prime}{ }_{j t}$ is a crisp number whose value is the graded mean integration representation of fuzzy numbers.

\section{Aggregate the rating of alternatives}

Let $r_{i j t}=\left(o_{i j t}, p_{i j t}, q_{i j t}\right), r_{i j t} \in \mathrm{R}+, i=1,2, \ldots, m, j=1,2, \ldots, n, t=1,2, \ldots, k$, be the suitable rating assigned to alternative $A_{i}$ by decision-makers $D_{t}$ with respect to criterion $C_{j}$. First, the rating $r_{i j t}$ can be transformed in to crisp numbers $r_{i j t}^{\prime}$, based on the graded mean integration representation of fuzzy numbers. Then, the aggregated rating $R_{i j}=\left(o_{i j}, p_{i j}, q_{i j}\right)$, of alternative $A_{i}$ with respect to criteria $C_{j}$ can be obtained as:

$$
R_{i j}=\frac{\sum_{t=1}^{K} r_{i j t}^{\prime}}{K}
$$

\section{Step 3: Construct the normalized decision matrix}

Assume that the decision matrix be $X=\left(x_{i j}\right)_{m \times n}$. The decision matrix for $m$ alternatives and $n$ criteria can be normalized as:

$S=\left[s_{i j}\right]_{m \times n}$

$$
\text { where } \mathrm{s}_{\mathrm{ij}}=\frac{\mathbf{r}_{\mathrm{ij}}}{\sqrt{\sum_{i=1}^{m}(\mathbf{r i j})^{2}}}
$$

\section{Step 4: Construct the weighted normalized decision matrix}

The normalized matrix multiplied by the normalized aggregate weights of the criteria gives the weighted normalized decision matrix.

Let the weighted normalized decision matrix be $V=\left(v_{i j}\right)_{m \times n}$. $v_{i j}=s_{i j} \times W_{j}$ 
where $i=1,2, \ldots, m$ and $j=1,2, \ldots, n$.

\section{Step 5: Determine the ideal and negative-ideal solutions}

The "positive-ideal solution" and the "negative-ideal solution" can be defined as:

$$
\begin{gathered}
A^{+}=\left(\widetilde{v}_{1}^{*}, \widetilde{v}_{2}^{*}, \ldots, \widetilde{v}_{n}^{*}\right) \\
A^{-}=\left(\widetilde{v}_{1}^{-}, \widetilde{v}_{2}^{-}, \ldots, \widetilde{v}_{n}^{-}\right)
\end{gathered}
$$

$$
\text { where } \widetilde{v}_{j}^{*}=\max _{i=1,2, \ldots, m}\left(\widetilde{v}_{i j}\right) \text { and } \widetilde{v}_{j}^{-}=\min _{i=1,2, \ldots, m}\left(\widetilde{v}_{i j}\right) \text {. }
$$

\section{Step 6: Calculate the distance of each alternative from $\mathrm{A}^{+}$and $\mathrm{A}^{-}$}

The distance of each alternative from $\mathrm{A}^{+}$and $\mathrm{A}^{-}$is now calculated, respectively, as follows:

$$
\begin{aligned}
& d^{+}=\sqrt{\sum_{j=1}^{n}\left(\widetilde{v}_{i j}-\widetilde{v}_{j}^{*}\right)^{2}} \\
& d^{1}=\sqrt{\sum_{j=1}^{n}\left(\tilde{v}_{i j}-\tilde{v}_{j}^{-}\right)^{2}}
\end{aligned}
$$

\section{Step 7: Calculate the closeness coefficient}

A closeness coefficient is defined to determine the ranking order of all alternatives once the $\mathrm{d}^{-}$of each alternative $\mathrm{A}_{\mathrm{i}}(\mathrm{i}=1,2, \ldots, \mathrm{m})$ has been calculated. The closeness coefficient of each alternative is calculated as:

$$
C C_{i}=\frac{d^{-}}{d^{+}+d^{-}}
$$

\section{Step 8: Find the ranks}

The alternatives are ranked based on their closeness coefficient to the ideal solution. If $C C_{i}$ is greater, then the best alternative will be $A_{i}$. An alternative will be the best alternative only with the largest relative closeness to the PIS.

\subsection{Proposed fuzzy TOPSIS}

In this work, in addition to the above methods we propose two more types of fuzzy TOPSIS based on Govindan et al., (2013) and Wang and Lee, (2007), which utilizes different methods of aggregating the evaluation made by the decision makers.

The fuzzy TOPSIS solution method consists of the following steps: (Hwang and Yoon 1981; Chen et al., 2006; Wang and Lee, 2007; Singh and Benyoucef, 2011).

\section{Step 1: Construct the fuzzy decision making matrix}

Let us consider a group of $k$ decision makers $\left(D_{1}, D_{2} \ldots \ldots . D_{k}\right)$ containing $m$ alternatives $\left(A_{1}\right.$, $\left.A_{2} \ldots \ldots . A_{m}\right)$ and $n$ criteria $\left(C_{1}, C_{2} \ldots \ldots . C_{n}\right)$ for a MCDM problem which is clearly expressed in a matrix format as: 


$$
D=\begin{gathered}
C_{1} \\
A_{1} \\
A_{2} \\
\vdots \\
A_{m}
\end{gathered}\left[\begin{array}{cccc}
r_{11} & r_{12} & \cdots & r_{1 n} \\
r_{21} & r_{22} & \cdots & r_{2 n} \\
\vdots & \vdots & \cdots & \vdots \\
r_{m 1} & r_{m 2} & \cdots & r_{m n}
\end{array}\right]
$$

Where, $\mathrm{r}_{\mathrm{mn}}$ be the rating of alternative $A_{\mathrm{m}}$ with respect to criteria $C_{\mathrm{n}}$ which is expressed as a linguistic triangular fuzzy number. Each decision maker evaluates the alternatives with respect to the criteria using the ratings given in Table 2 . In order to aggregate the decisions on alternatives made by each decision maker, we use definition 6 mentioned in section 4.1.

\section{Step 2: Normalize the aggregated fuzzy decision matrix}

The data in the aggregated fuzzy decision matrix are normalized to remove the anomalies with different measurement units and scales available in the problem (Singh and Benyoucef, 2011). The normalized aggregated fuzzy-decision matrix can be represented as:

$\mathrm{R}=\left[\mathrm{r}_{\mathrm{i} j}\right]_{\mathrm{m}, \mathrm{m}}$

The normalized values for benefit and cost related criteria are calculated using eqs. (19 and 20).

$r_{i j}=\left(\frac{a_{i j}}{c_{j}^{*}}, \frac{b_{i j}}{c_{j}^{*}}, \frac{c_{i j}}{c_{j}^{*}}\right), j \in B$

$c_{j}^{*}=\max _{i} c_{i j}, j \in B$

$r_{i j}=\left(\frac{a_{j}^{-}}{c_{i j}}, \frac{a_{j}^{-}}{b_{i j}}, \frac{a_{j}^{-}}{a_{i j}}\right), j \in C$

$a_{j}^{-}=\min _{\mathrm{i}} a_{\mathrm{i} j}, j \in C$

Where, $\mathrm{B}$ and $\mathrm{C}$ are the sets of benefit and cost criteria respectively.

Step 3: Construct the Weighted normalized fuzzy decision matrix

The Weighted normalized fuzzy decision matrix $v_{i j}$ is calculated by multiplying the normalized matrix with the weights of the evaluation criteria. The Weighted normalized fuzzy decision matrix $\mathrm{V}$ is defined as follows:

$\mathrm{V}=\left[v_{i j}\right]_{m, n} i=1,2, \ldots, m j=1,2, \ldots, n$

Where $v_{i j}=n_{i j} \cdot w_{j}$ and $w_{j}$ is the weight of the $j^{\text {th }}$ criterion.

Step 4: Determine the fuzzy positive-ideal solution ( $\left.A^{*}\right)$ and fuzzy negative-ideal solution ( $\left.A^{-}\right)$

The fuzzy positive-ideal solution (FPIS, $A^{*}$ ) and negative-ideal solution (NIS, $A^{-}$) can be calculated as:

$A^{*}=\left(v_{1}^{*}, v_{2}^{*}, \ldots, v_{n}^{*}\right)$

$A^{-}=\left(v_{1}^{-}, v_{2}^{-}, \ldots, v_{n 1}^{-}\right)$

Where, $v_{j}^{*}=\max _{i}\left\{v_{i j}\right\}$ and $v_{j}^{-}=\min _{i}\left\{v_{i j}\right\}, \mathrm{i}=1,2, \ldots, \mathrm{m}, \mathrm{j}=1,2, \ldots, \mathrm{n}$

Step 5: Calculate the distance of each alternative from FPIS and FNIS

The distance of each alternative from FPIS and FNIS are calculated as follows:

$d_{i}^{*}=\sum_{j=1}^{n} d_{v}\left(v_{i j}, v_{j j}^{*}\right), \mathrm{i}=1,2, \ldots, \mathrm{m}$

$d_{i}^{-}=\sum_{j=1}^{n} d_{v}\left(v_{i j}, v_{j}^{-}\right), i=1,2, \ldots, m$

Where, $\mathrm{d}_{v}\left(\mathrm{v}_{i j}, \mathrm{~V}_{j}{ }^{*}\right)$ denotes the distance between two fuzzy numbers and is calculated by equation. (7).

Step 6: Obtain the closeness coefficient $\left(C C_{I}\right)$ 
The closeness coefficient $\left(C C_{I}\right)$ of each alternative is calculated as:

$C C_{V}=\frac{\boldsymbol{d}_{\mathbf{i}}}{\boldsymbol{d}_{\boldsymbol{i}}+d_{\boldsymbol{i}}^{*}}, \mathrm{i}=1,2, \ldots, \mathrm{m}$

\section{Step 7: Rank determination}

At the end of the analysis, the ranking of alternatives is determined by comparing $C C_{i}$ values. Alternative $A_{\mathrm{i}}$ is closer to the FPIS $\left(A^{*}\right)$ and further from FNIS $\left(A^{-}\right)$as $C C_{I}$ approaches to 1 . the ranking order of all alternatives determines according to the descending order of $C C_{I}$. The alternative $\mathrm{A}_{i}$ will be the best only if its $C C_{i}$ is higher.

\subsection{Spearman rank correlation coefficient}

By applying the previously discussed methods to the case problem, we obtain the ranks based on graded mean integration fuzzy TOPSIS, geometric mean based fuzzy TOPSIS (Chen et al., 2011), and proposed fuzzy TOPSIS. The major issue before taking the final decision is the reliability of the results (Kahraman et al., 2009). The Spearman rank correlation coefficient (R) is one of the useful and important measures (Chamodrakas et al., 2011) to determine the measure of association between ranks obtained by different approaches (Raju and Kumar, 1999).

In this paper we used Spearman's rank-correlation test to find the statistical significance of the difference between the ranking obtained using the proposed fuzzy TOPSIS and the ones obtained from the graded mean integration fuzzy TOPSIS and geometric mean based fuzzy TOPSIS. The Spearman co-efficient is defined as follows (Raju and Kumar, 1999):

$$
R=1-\frac{6 \sum_{a=1}^{A} D_{a}^{2}}{A\left(A^{2}-1\right)},
$$

Where, $\mathrm{a}=$ number of alternatives; $\mathrm{A}=$ total number of alternatives; $\mathrm{D}_{\mathrm{a}}=$ difference between ranks obtained through two different methods. $\mathrm{R}=1$ represents perfect association between the ranks; $\mathrm{R}=0$ represents no association between the ranks; $\mathrm{R}=-1$ represents perfect disagreement between the ranks.

\section{Application of the proposed model}

In this work, a five-phase methodology is utilized to select the green suppliers based on 12 suppliers of a Brazilian electronics company and the methodology is described as follows:

Phase 1:

In phase 1, the criteria used for the green supplier selection is identified through literature. The researcher develops the questionnaire to obtain the weight preference for the criteria and to rate the alternatives based on the criteria.

\section{Phase 2:}

In the second phase, a questionnaire was send to the academic experts' team for content analysis. Based on the review of four academicians, the questionnaire was improved.

\section{Phase 3:}

In the third phase, three decision makers, who work with the marketing context of GSCM are invited to evaluate the alternatives of improved questionnaire. In order to determine the weights of the criteria used in the study and to evaluate the alternatives the decision makers are asked to complete the questionnaires $^{2}$ using the linguistic terms given in Table 2 and 3 . The fuzzy weights of each criterion

\footnotetext{
${ }^{2}$ A sample questionnaire is provided in Appendix 1.
} 
based on each decision maker are presented in Table 4 and the fuzzy decision matrix for each decision maker is given in Table $5 \mathrm{a}$ to $5 \mathrm{c}$.

$* * * * * * * *$ Table $4,5 a, 5 b \& 5$ about here $* * * * * * * * *$

\section{Phase 4:}

In this phase, the fuzzy TOPSIS methodology proposed in section 4.3 is used to rank the green suppliers. The fuzzy weights of each criterion (Table 4) and fuzzy decision matrix (Tables 5a, 5b \& $5 \mathrm{c})$ from the above phase are used to find the aggregated weights of each criterion $\left(W_{j}\right)$ and aggregated ratings of each alternative $\left(R_{i j}\right)$ by using equation 8 . Depending on the benefit or cost criteria, the obtained fuzzy decision matrix is normalized by following eqs 19 and 20. Then the weights of the evaluation criteria are multiplied with the normalized matrix to form a weighted normalized fuzzy decision matrix (by equation 21).

After obtaining the weighted normalized fuzzy decision matrix, FPIS and FNIS are determined using eqs. 22 and 23 respectively. As a next step, the distance of the suppliers from the FPIS and FNIS is calculated using eqs. 24 and 25. In order to rank the green suppliers based on their closeness to the FPIS and remoteness to the FNIS, the closeness coefficient is calculated using equation 26. Depending on the maximum closeness of the alternatives to the FPIS, ranks are given for the chosen alternatives of green suppliers.

The aggregated weights of each criterion, aggregated ratings of each alternative, normalized decision matrix, the distance of each supplier to FPIS and FNIS, closeness coefficient, and ranks obtained by each suppliers are shown in Tables 6-11 respectively.

\section{$* * * * * * * *$ Tables 6 to 11 about here $* * * * * * * * *$}

In order to receive some feedback from the management, the fuzzy TOPSIS results obtained were discussed. After the discussion, management raised a question about the reliability of the proposed fuzzy methodology results. They also suggested to compare the current results with other fuzzy approaches for validity. Hence, we utilized the two known other fuzzy TOPSIS methods (graded mean integration fuzzy TOPSIS and geometric mean based fuzzy TOPSIS) for comparison purposes. The final ranks of the other two fuzzy TOPSIS approaches are shown in Table 12.

$* * * * * * * * *$ Tables 12 about here $* * * * * * * * *$

\section{Phase 5:}

In the fifth phase, the Spearman rank correlation coefficient is calculated to find the statistical difference between the ranks obtained through all three methods. The Spearman co-efficient (R) between the graded mean integration fuzzy TOPSIS, geometric mean based fuzzy TOPSIS, and proposed fuzzy TOPSIS is shown in Table 13. From Table 13, it is inferred that the value of $\mathrm{R}$ is in between 0.930 to 0.993 , which indicates that there occurs a nearly perfect association between the methods. There is no significant difference in ranks obtained between our proposed method and the geometric mean based fuzzy TOPSIS.

$* * * * * * * * *$ Table 13 about here $* * * * * * * * *$

\subsection{Final Results}

The results obtained from the proposed fuzzy TOPSIS approach for the MCDM problem of green supplier selection required for the Brazilian electronics companies are summarized and shown in the 
Table 12. Based on the closeness coefficient, the ranks obtained using three types of fuzzy TOPSIS methods for the available 12 green suppliers are summarized as follows:

1) By proposed fuzzy TOPSIS method A $5>$ A $10>$ A $3>$ A $12>$ A $4>$ A $11>$ A $7>$ A $2>$ A $9>$ A $8>$ A6 $>$ A 1

2) By Geometric mean method of fuzzy TOPSIS

$$
\text { A } 10>\text { A } 5>\text { A } 3>\text { A } 12>\text { A } 4>\text { A } 11>\text { A } 7>\text { A2 }>\text { A9 }>\text { A } 8>\text { A6 }>\text { A } 1
$$

3) By Graded mean method of fuzzy TOPSIS

$$
\text { A } 12>\text { A } 3>\text { A } 5>\text { A } 10>A 4>A 11>A 7>A 2>A 9>A 8>A 6>A 1
$$

From the obtained results, we can conclude that the supplier 5 and supplier 10 get first preference to be selected for the green supplier under two types of fuzzy TOPSIS method (namely, the proposed method and the geometric mean method, respectively). Results acquired from Table 13 for the Spearman rank correlation coefficient emphasize that the $\mathrm{R}$ value establishes a nearly perfect association between the proposed method and geometric mean method of fuzzy TOPSIS methodology.

\section{Sensitivity analysis}

The sensitivity analysis is performed to examine the influence of the preferences given by the decision makers for GSCM practices on the selection of green suppliers. To perform the sensitivity analysis, we ranked the major and minor influencing GSCM practices from Table 6. The weights of major and minor influencing GSCM practices vary from very low (VL) preference to very high (VH) preference. The ranking of various GSCM practices is shown in Table 14. From Table 14, the major influencing criteria are ranked 1 and 2 (i.e., Commitment of senior management to GSCM; Product designs that reduce, reuse, recycle, or reclaim materials, components, or energy; Compliance with legal environmental requirements and auditing programs; Product designs that avoid or reduce toxic or hazardous material use). Minor influencing practices are ranked 8 and 9 (i.e., Sale of used equipment (after buying new equipment); Sale of scrap and used materials).

In order to perform the sensitivity analysis, 22 cases were conducted. In the first ten cases (case 1 to case 10), the decision makers' preference for rank 1 criteria $(\mathrm{C} 1$ and $\mathrm{C} 13)$ are varied from VL to $\mathrm{VH}$ (VL, L, M, H, VH) by maintaining the other criteria preference as shown in Table 4. In the next ten cases (case 11 to case 20), the decision makers' preference for rank 2 criteria (C3 and C14) are also varied from VL to $\mathrm{VH}(\mathrm{VL}, \mathrm{L}, \mathrm{M}, \mathrm{H}, \mathrm{VH})$ by maintaining the other criteria preference as shown in Table 4. In the 2lst case, the preference between rank 1 and rank 9 criteria is interchanged and, in the last case, the preference between rank 2 and rank 8 criteria is similarly interchanged. Details of the 22 cases are shown in Table 15, and the closeness coefficient and ranking of the 22 cases is shown both in Table 16 and Figure 4. From Table 16 and Figure 4 one can see that the ranking of green suppliers changed a bit with respect to different preferences of criteria, but green supplier 5 is still the preferred alternative in all 22 cases.

$* * * * * * * * *$ Table 14-16 about here $* * * * * * * * *$

\section{Conclusion}

GSCM is still a relatively new concept in Brazil, but companies have started to realize the importance of GSCM due to the Brazilian government's legislation on reverse logistics. As a result, many companies have begun to demonstrate their commitment to implementing GSCM principles (Jabbour et al., 2013a). This research work presents an extension of the classical TOPSIS method called fuzzy 
TOPSIS methodology for solving a real world MCDM problem of green supplier selection based on the GSCM practices which deals with linguistic environments. In this work, three types of fuzzy TOPSIS - the proposed method, the geometric mean method, and graded mean method - are utilized to rank green suppliers according to the value given to carry out the GSCM practices in the company. The proposed framework is demonstrated and validated by a numerical example taken from a Brazilian company that assembles electronics equipment. The results obtained through the proposed framework are compared with the results attained by the geometric and graded mean methods. The foremost concern in any good decision making model is the reliability of the results. In order to obtain reliable results through the proposed framework, the Spearman rank correlation coefficient has been applied. Its results also suggest that there is nearly a perfect association between the ranks obtained by the proposed method and the geometric mean method of fuzzy TOPSIS. Thus, the obtained results allow the company to select the best green suppliers to enhance their supply chain management.

The results indicate that the major influencing criteria for GSCM practices include: Commitment of senior management to GSCM; Product designs that reduce, reuse, recycle, or reclaim materials, components, or energy; Compliance with legal environmental requirements and auditing programs; and Product designs that avoid or reduce toxic or hazardous material use. Top management support is a fundamental requirement for a company to manufacture environmentally-friendly products, and a primary decision rests on which supplier will enhance the green supply chain of a company. In Brazil, suppliers need to be trained to review procedures for product design and to more proactively embrace environmental management practices.

While we have selected the best supplier through fuzzy TOPSIS, limitations may exist in terms of capacity, delivery lead time, and so forth. These potential limitations should be considered when integrating this MCDM model into the allocation model. However, recognizing these potential limitations also forms the basis for future work. Other possible techniques that might be employed for future research include VIKOR and PROMETHEE; results obtained from these methods could be compared with the results obtained from this work.

\section{References}

1. Ageron, B., Gunasekaran, A., \& Spalanzani, A. (2012). Sustainable supply management: an empirical study. International Journal of Production Economics, 140 (1), 168-182.

2. Ahi, P., \& Searcy, C. (2013). A Comparative Literature Analysis of Definitions for Green and Sustainable Supply Chain Management. Journal of Cleaner Production, 52, 329-341.

3. Akamp, M., \& Müller, M. (2011). Supplier management in developing countries. Journal of Cleaner Production, in press.

4. Awasthi, A., Chauhan, S. S., \& Omrani, H. (2011). Application of fuzzy TOPSIS in evaluating sustainable transportation systems. Expert Systems with Applications, 38, 12270-12280.

5. Baskaran, V., Nachiappan, S., \& Rahman, S. (2012). Indian textile suppliers' sustainability evaluation using the grey approach. International Journal of Production Economics, 135, 647- 658.

6. Bellman, R. E., \& Zadeh, L. A. (1970). Decision-making in a fuzzy environment. Journal of management Science, 17 (4), 141-164.

7. Büyükozkan, G., \& Çifçi, G. (2012). A novel hybrid MCDM approach based on fuzzy DEMATEL, fuzzy ANP and fuzzy TOPSIS to evaluate green suppliers. Expert Systems with Applications, 39, 30003011.

8. Büyüközkan, G., \& Çifçi, G. (2011). A novel fuzzy multi-criteria decision framework for sustainable supplier selection with incomplete information. Computers in Industry, 62(2), 164-174. 
9. Chamodrakas, I., Leftheriotis, I., \& Martakos, D. (2011). In-depth analysis and simulation study of an innovative fuzzy approach for ranking alternatives in multiple attribute decision making problems based on TOPSIS. Applied Soft Computing, 11 (1), 900-907.

10. Chang, Y. H., \& Yeh, C. H. (2002). A survey analysis of service quality for domestic airlines. European Journal of Operational Research, 139, 166-177.

11. Chang, Y. H., Chung, H. Y., \& Wang, S. Y. (2007). A survey and optimization-based evaluation of development strategies for the air cargo industry. International Journal of Production Economics, 106, $550-562$.

12. Chen, C. T., Lin, C. T., \& Huang, S. F. (2006). A fuzzy approach for supplier evaluation and selection in supply chain management. International Journal of Production Economics, 102, 289-301.

13. Chen, V. Y., Lien, H. P., Liu, C. H., Liou, J. J., Tzeng, G. H., \& Yang, L. S. (2011). Fuzzy MCDM approach for selecting the best environment-watershed plan. Applied Soft Computing, 11(1), 265-275.

14. Dekker, R., Bloemhof, J., \& Mallidis, I. (2012). Operations research for green logistics - an overview of aspects, issues, contributions and challenges. European Journal of Operational Research, 219, 671679.

15. Deviren, M., Yavuz, S., \& K1lınc, N. (2009). Weapon selection using the AHP and TOPSIS methods under fuzzy environment. Expert Systems with Applications, 36, 8143-8151.

16. Diabat, A., Khodaverdi, R., \& Olfat, L. (2013). An exploration of green supply chain practices and performances in an automotive industry. The International Journal of Advanced Manufacturing Technology, in press.

17. Dües, C. M., Tan, K. H., \& Lim, M. (2013). Green as the new lean: how to use lean practices as a catalyst to greening your supply chain. Journal of Cleaner Production, 40, 93-100.

18. Genovese, A., Lenny Koh, S. C., Bruno, G., \& Esposito, E. (2013). Greener supplier selection: state of the art and some empirical evidence. International Journal of Production Research, 51 (10), 2868-2886

19. Govindan, K., Khodaverdi, R., \& Jafarian, A. (2013). A fuzzy multi criteria approach for measuring sustainability performance of a supplier based on triple bottom line approach. Journal of Cleaner Production, 47, 345-354.

20. Gumus, A. T. (2009). Evaluation of hazardous waste transportation firms by using a two step fuzzyAHP and TOPSIS methodology. Expert Systems with Applications, 36, 4067-4074.

21. Gunasekaran, A., \& Ngai, E.W.T. (2012). The future of operations management: an outlook and analysis. International Journal of Production Economics, 135, 687-701.

22. Gunasekaran, A., \& Gallear, D. (2012). Sustainable development of manufacturing and services. International Journal of Production Economics, in press.

23. Handfield, R., Walton, S.V., Sroufe, R., \& Melnyk, S. (2002). Applying environmental criteria to supplier assessment. European Journal of Operational Research, 141 (1), 70-87.

24. Hart, S. L., \& Dowell, G. (2011). Invited Editorial: A Natural-Resource-Based View of the Firm Fifteen Years After. Journal of Management, 37(5), 1464-1479.

25. Hsu, C., \& Hu, A.H. (2009). Applying hazardous substance management to supplier selection using analytic network process. Journal of Cleaner Production, 17, 255-264.

26. Humphreys, P. K., Wong,Y. K., \& Chan, F. T. S. (2003). Integrating environmental criteria into the supplier selection process. Journal of Materials Processing Technology, 138(1-3), 349-56.

27. Hwang, C. L., \& Yoon, K. (1981). Multiple attribute decision making methods and application. New York: Springer-Verlag.

28. Jabbour, A. B. L. S., Jabbour, C. J. C., Sarkis, J., \& Govindan, K. (2013a). Brazil's new national policy on solid waste: challenges and opportunities. Clean Technologies and Environmental Policy, in press.

29. Jabbour, A. B. L. S., \& Jabbour, C. J. C. (2009). Are supplier selection criteria going green? Case studies of companies in Brazil. Industrial Management \& Data Systems, 109(4), 477 - 495.

30. Jabbour, A. B. L. S., Azevedo, F. S., Arantes, A. F., \& Jabbour, C. J. C. (2013b). Green supply chain management in local and multinational high-tech companies located in Brazil. International Journal of Advanced Manufacturing Technology, in press.

31. Jabbour, C. J. C., \& Jabbour, A.B.L.S. (2013). Latin America: research opportunities on management for Sustainable Development. Latin American Journal of Management for Sustainable Development, in press.

32. Kahraman, C., Bes_kese, A., \& Ruan, D. (2004). Measuring flexibility of computer integrated manufacturing systems using fuzzy cash flow analysis. Information Sciences, 168, 77-94. 
33. Kahraman, C., Engin, O., Kabak, O., \& Kaya, I. (2009). Information system outsourcing decisions using a group decision-making approach. Engineering Applications of artificial intelligence, 22, 832841.

34. Kannan, G., Pokharel, S., \& Sasi Kumar, P. (2009). A hybrid approach using ISM and fuzzy TOPSIS for the selection of reverse logistics provider. Resources, Conservation and Recycling, 54, 28-36.

35. Kleindorfer, P. R., Singhal, K., \& Wassenhove, L. N. (2005). Sustainable operations management. Production and operations management, 14(4), 482-492.

36. Kulak, O., Durmusoglu, B., \& Kahraman, C. (2005). Fuzzy multi-attribute equipment selection based on information axiom. Journal of Materials Processing Technology, 169, 337-345.

37. Kumar, A., Jain, V., \& Kumar, S. (2014). A comprehensive environment friendly for supplier selection. Omega, 42 (1), 109-13.

38. Kuo, R. J., Wang, Y. C., \& Tien, F. C. (2010). Integration of artificial neural network and MADA methods for green supplier selection. Journal of Cleaner Production, 18(12), 1161-1170.

39. Lai, K. H., \& Wong, C. W. (2012). Green logistics management and performance: Some empirical evidence from Chinese manufacturing exporters. Omega, 40(3), 267-282.

40. Large, R.O., \& Thomsen, C.G. (2011). Drivers of green supply management performance: evidence from Germany. Journal of Purchasing \& Supply Management, 17, 176-184.

41. Lee, A.H. I., Kang, H., Hsu, C., \& Hung, H. (2009). A green supplier selection model for high-tech industry. Expert Systems with Applications, 36, 7917-7927.

42. Linton, J. D., Klassen, R., \& Jayaraman, V. (2007). Sustainable supply chains: an introduction. Journal of Operations Management, 25(6), 1075-1082.

43. Marcus, A., \& Fremeth, A. (2009). Green management matters regardless. The Academy of Management Perspectives, 23(3), 17-26.

44. Min, H., \& Kim, H. (2012). Green supply chain research: past, present, and future. Logistics Research, 4, 39-47.

45. Min, H., \& Galle, W. P. (2001). Green purchasing practices of US firms. International Journal of Operations \& Production Management, 21 (9), 1222-1238.

46. Olfat, A., Govindan, K., \& Khodaverdi, R. (2012). A fuzzy multi criteria approach for evaluating green supplier's performance in green supply chain with linguistic preferences. Resources, Conservation and Recycling, working paper.

47. Raju, K.S., \& Kumar, D.N. (1999). Multicriterion decision making in irrigation planning. Agricultural Systems, 62, 117-129.

48. Rao, P., \& Holt, D. (2005). Do green supply chains lead to competitiveness and economic performance?. International Journal of Operations \& Production Management, 25(9), 898-916.

49. Sarkis, J. (1998). Evaluating environmentally conscious business practices. European Journal of Operational Research, 107, 159-174.

50. Sarkis, J. (2003). A strategic decision framework for green supply chain management. Journal of Cleaner Production, 11(4), 397-409.

51. Sarkis, J. (2012). Models for compassionate operations. International Journal of Production Economics, in press.

52. Sarkis, J., Zhu, Q., \& Lai, K. (2011). An organizational theoretic review of Green supply chain management literature. International Journal of Production Economics, 130, 1-15.

53. Seuring, S. (2013). A review of modeling approaches for sustainable supply chain management. Decision Support System 54, 1513-1520

54. Seuring, S., \& Müller, M. (2008). From a literature review to a conceptual framework for sustainable supply chain management. Journal of Cleaner Production, 16(15), 1699-1710.

55. Shaw, K., Shankar, R., Yadav, S. S., \& Thakur, L. S. (2012). Supplier selection using fuzzy AHP and fuzzy multi-objective linear programming for developing low carbon supply chain. Expert Systems with Applications, 39(9), 8182-8192.

56. Sheu, J. B., Chou, Y. H., \& Hu, C. C. (2005). An integrated logistics operational model for greensupply chain management. Transportation Research Part E: Logistics and Transportation Review, 41(4), 287-313.

57. Singh, R. K. \& Benyoucef, L. (2011). A fuzzy TOPSIS based approach for e-sourcing. Engineering Applications of Artificial Intelligence, 24(3), 437-448. 
58. Srivastava, S. K. (2007). Green supply chain management: a state of the art literature review. International Journal of Management Reviews, 9(1), 53-80.

59. Tomasin da Silva, L., Pereira, G. M., Borchardt, M., \& Sellitto, M. A. (2013). How can the sales of green products in the Brazilian supply chain be increased?. Journal of Cleaner Production, 47, 274282.

60. Torlak, G., Sevkli, M., Sanal, M., \& Zaim, S. (2011). Analyzing business competition by using Fuzzy Topsis method: An Example of Turkish domestic airline industry. Expert Systems with Applications, 38(4), 3396-3406.

61. Tseng, M. L., \& Chiu, A. S. (2013). Evaluating firm's green supply chain management in linguistic preferences. Journal of Cleaner Production, 40, 22-31.

62. Vachon, S., \& Klassen, R. D. (2006). Extending green practices across the supply chain: the impact of upstream and downstream integration. International Journal of Operations \& Production Management, 26(7), 795-821.

63. Wang, X., \& Chan, H. K. (2013). A hierarchical fuzzy TOPSIS approach to assess improvement areas when implementing green supply chain initiatives. International Journal of Production Research, (ahead-of-print), 1-14.

64. Wang, Y. J., \& Lee, H. S. (2007). Generalizing TOPSIS for fuzzy multiple-criteria group decisionmaking. Computers and Mathematics with Applications, 53, 1762-1772.

65. Wolf, C., \& Seuring, S. (2010). Environmental impacts as buying criteria for third party logistical services. International Journal of Physical Distribution \& Logistics Management, 40 (1/2), 84-102.

66. Xiong, Y., Zhou, Y., Li, G., \& Chan, H. (2013). Don't forget your supplier when remanufacturing. European Journal of Operational Research, 230, 15-25.

67. Yang, C. S., Lu, C. S., Haider, J. J., \& Marlow, P. B. (2013). The effect of green supply chain management on green performance and firm competitiveness in the context of container shipping in Taiwan. Transportation Research Part E: Logistics and Transportation Review, 55(1), 55-73.

68. Yeh, W. C., \& Chuang, M. C. (2011). Using multi-objective genetic algorithm for partner selection in green supply chain problems. Expert Systems with Applications, 38(4), 4244-4253.

69. Yu, C. S. (2002). A GP-AHP method for solving group decision-making fuzzy AHP problems. Computers and Operations Research, 29, 1969-2001.

70. Yu, V. F., Dat, L. Q., Quang, N. H., Son, T. A., Chou, S. Y., \& Lin, A. C. (2012). An extension of fuzzy TOPSIS approach based on centroid-index ranking method. Scientific Research and Essays, 7(14), 1485-1493.

71. Zadeh, L. (1976). A fuzzy-algorithmic approach to the definition of complex or imprecise concepts. International Journal of Man-Machine Studies, 8, 249-291.

72. Zadeh, L. A. (1965). Fuzzy sets. Journal of Information and Control, 8, 338-353.

73. Zhu, Q., \& Sarkis, J. (2004). Relationships between operational practices and performance among early adopters of green supply chain management practices in Chinese manufacturing enterprises. Journal of Operations Management, 22(3), 265-289.

74. Zhu, Q., Sarkis, J., \& Lai, K. (2008). Confirmation of a measurement model for Green supply chain management practices implementation. International Journal of Production Economics, 111, 261-273.

75. Zhu, Q., Sarkis, J., \& Geng, Y. (2005). Green supply chain management in China: pressures, practices and performance. International Journal of Operations \& Production Management, 25(5), 449-468.

76. Zimmerman, H. J. (1996). Fuzzy sets theory and its applications. Boston: Kluwer Academic Publishers. 


\section{Appendix-A}

Greetings!

This research addresses "Selecting green suppliers based on GSCM practices: Using Fuzzy TOPSIS applied to a Brazilian electronics company."

The below table A refers to the format of the questionnaire used to determine the preference or importance given by the decision makers for the various available criteria, namely the GSCM practices that have been considered for the green supplier selection. Likewise, table B shows the questionnaire format used to determine the ratings given for the chosen alternatives, namely the green suppliers by the decision makers based on the identified 17 criteria. The tick mark ( table $A$ the order preference ranges used varies from Very low (VL), Low (L), Medium (M), High (H) and Very high (VH) ${ }^{1}$. Also table B shows the order preference ranging from Very poor (VP), Poor (P), Medium poor (MP), Fair (F), Medium good (MG) and Good (G) ${ }^{2}$.For example, from table B, it is obvious that the decision maker gives low (L) importance to the GSCM1 practice called senior manager commitment to the GSCM practices. And table B shows that the decision maker gives medium poor (MP) rating/importance to the Supplier1 based on the criteria 1 namely the GSCM1.

Table A: Questionnaire used to find the decision maker's preference for the identified criteria.

\begin{tabular}{|l|l|l|l|l|l|}
\hline Criteria & VL & L & M & H & VH \\
\hline GSCM1 & & S $^{+}$ & & & \\
\hline GSCM2 & & & & & \\
\hline$\cdot$ & & & & & \\
$\cdot \cdot$ & & & & & \\
\hline GSCM17 & & & & & \\
\hline
\end{tabular}

${ }^{1}$ The definition of preference ranges can be found from table 3.

22 The definition of preference ranges can be found from table 2 . 
Table B: Questionnaire used to find the decision maker's preference for the available alternatives based on the identified criteria

\begin{tabular}{|c|c|c|c|c|c|c|c|c|c|c|c|c|c|c|c|c|c|c|c|c|c|c|}
\hline & \multicolumn{6}{|c|}{$\mathrm{C} 1$} & \multicolumn{8}{|c|}{$\mathrm{C} 2$} & $\ldots$ & \multicolumn{7}{|c|}{ C17 } \\
\hline ALTERNATIVE & VP & $\mathrm{P}$ & $\mathrm{MP}$ & $\mathrm{F}$ & MG & $\mathrm{G}$ & VG & VP & $P$ & MP & $\mathrm{F}$ & $M G$ & G & VG & & VP & $\mathrm{P}$ & $\mathrm{MP}$ & $\mathrm{F}$ & MG & $\mathrm{G}$ & VG \\
\hline A1 & & & & & & & & & & & & & & & & & & & & & & \\
\hline $\mathrm{A} 2$ & & & & & & & & & & & & & & & & & & & & & & \\
\hline $\begin{array}{l}\text {. } \\
\text {. } \\
\text {. }\end{array}$ & & & & & & & & & & & & & & & & & & & & & & \\
\hline A12 & & & & & & & & & & & & & & & & & & & & & & \\
\hline
\end{tabular}


Table 1a: Top ten cited works in green supply chain management

\begin{tabular}{|c|c|}
\hline Author(s) & Purpose/Findings \\
\hline $\begin{array}{l}\text { Srivastava } \\
(2007)\end{array}$ & $\begin{array}{l}\text { Classified the available literature on GSCM into categories such as problem context; } \\
\text { methodology/approach; and tools and techniques. Supplied a comprehensive review of the literature } \\
\text { on green supply chain. }\end{array}$ \\
\hline $\begin{array}{l}\text { Zhu and Sarkis } \\
(2004)\end{array}$ & $\begin{array}{l}\text { Used empirical results from more than } 180 \text { respondents on GSCM practices in Chinese } \\
\text { manufacturing firms to examine the relationships between GSCM practices and environmental and } \\
\text { economic performance. }\end{array}$ \\
\hline Sarkis (2003) & $\begin{array}{l}\text { Presented a decision framework that considers green management factors, designed to facilitate } \\
\text { improvements in green supply chain management decision making. }\end{array}$ \\
\hline $\begin{array}{l}\text { Seuring and } \\
\text { Mueller (2008) }\end{array}$ & $\begin{array}{l}\text { Reviewed and classified the literature on sustainable supply chain management, including green } \\
\text { issues, and presented an overview of state of the art literature. }\end{array}$ \\
\hline $\begin{array}{l}\text { Rao and Holt } \\
\text { (2005) }\end{array}$ & $\begin{array}{l}\text { Tested linkages between green supply chain management as an initiative for environmental } \\
\text { enhancement, economic performance and competitiveness among a sample of ISO14001-certified } \\
\text { companies in Southeast Asia. They found positive relationships in the studied model. }\end{array}$ \\
\hline $\begin{array}{l}\text { Kleindorfer et } \\
\text { al. }(2005)\end{array}$ & $\begin{array}{l}\text { Reviewed various themes on sustainability (including green supply chain management). Covered } \\
\text { Production and Operations Management journal. They highlighted future research challenges in } \\
\text { sustainable operations management. }\end{array}$ \\
\hline $\begin{array}{l}\text { Linton et al. } \\
\text { (2007) }\end{array}$ & $\begin{array}{l}\text { Presented a special issue on sustainable supply chain management. Reinforced the argument that the } \\
\text { focus on environmental management and operations has now moved from local optimization of } \\
\text { environmental factors to consideration of the entire supply chain. }\end{array}$ \\
\hline $\begin{array}{l}\text { Zhu et al. } \\
(2005)\end{array}$ & $\begin{array}{l}\text { Based on } 314 \text { complete questionnaires, authors concluded that more awareness on environmental } \\
\text { issues has not yet been translated into strong GSCM practice adoption. }\end{array}$ \\
\hline $\begin{array}{l}\text { Vachon and } \\
\text { Klassen (2006) }\end{array}$ & $\begin{array}{l}\text { Conceptualized and empirically tested green supply chain practices, and considered both upstream } \\
\text { and downstream interactions in chain. }\end{array}$ \\
\hline $\begin{array}{l}\text { Sheu et al. } \\
(2005)\end{array}$ & $\begin{array}{l}\text { Presented an optimization-based model to deal with integrated logistics operational problems of } \\
\text { green-supply chain management. }\end{array}$ \\
\hline
\end{tabular}

Table 1b: GSCM practices used in this article

\begin{tabular}{|c|c|c|}
\hline Code & Name of the Practice & Explanation \\
\hline GSCM 1 & $\begin{array}{l}\text { Commitment of senior } \\
\text { management to GSCM }\end{array}$ & $\begin{array}{l}\text { The support of senior management is crucial in GSCM adoption, as there } \\
\text { will be an eventual need for process adjustments or cultural changes. }\end{array}$ \\
\hline GSCM 2 & $\begin{array}{l}\text { Inter-functional } \\
\text { cooperation for } \\
\text { environmental } \\
\text { improvement }\end{array}$ & $\begin{array}{l}\text { Inter-functional cooperation (e.g., purchases and sustainability, research } \\
\text { and development in sustainability, or marketing and stability, etc.) is } \\
\text { important in implementing changes in the day-to-day activities of the } \\
\text { functional areas. This type of cooperation can therefore promote } \\
\text { environmental requirements externally via upstream suppliers, or internally } \\
\text { via consumer demand. }\end{array}$ \\
\hline GSCM 3 & $\begin{array}{l}\text { Compliance with legal } \\
\text { environmental } \\
\text { requirements and } \\
\text { auditing programs }\end{array}$ & $\begin{array}{l}\text { Addressing environmental legal requirements and auditing programs } \\
\text { demonstrates that the company is attempting to meet environmental } \\
\text { regulation for their sector internally. }\end{array}$ \\
\hline GSCM 4 & ISO 14001 Certification & The company has an ISO $14001 \mathrm{ce}$ \\
\hline GSCM 5 & $\begin{array}{l}\text { Selection of suppliers } \\
\text { includes environmental } \\
\text { criteria }\end{array}$ & $\begin{array}{l}\text { The selection process for suppliers considers environmental variables (e.g., } \\
\text { ISO 14001) in addition to traditional criteria (e.g., cost, quality, reliability, } \\
\text { etc.). }\end{array}$ \\
\hline GSCM 6 & $\begin{array}{l}\text { Work with suppliers to } \\
\text { meet environmental goals }\end{array}$ & $\begin{array}{l}\text { Suppliers are asked to support initiatives and measures within their } \\
\text { company to improve the environment. }\end{array}$ \\
\hline GSCM 7 & $\begin{array}{l}\text { Evaluations of the } \\
\text { internal environmental } \\
\text { management of suppliers }\end{array}$ & $\begin{array}{l}\text { Inspections of supplier installations provide a way to check the } \\
\text { environmental performance of the supplier and ensure that they comply } \\
\text { with environmental management standards. }\end{array}$ \\
\hline GSCM 8 & $\begin{array}{l}\text { Evaluation of the } \\
\text { environmental } \\
\text { management of } 2^{\text {nd }} \text {-tier } \\
\text { suppliers }\end{array}$ & $\begin{array}{l}\text { Suppliers of basic raw materials are also monitored to extend } \\
\text { environmental concern beyond the direct relationship. }\end{array}$ \\
\hline
\end{tabular}




\begin{tabular}{|l|l|l|}
\hline GSCM 9 & $\begin{array}{l}\text { Work with clients for } \\
\text { eco-design }\end{array}$ & $\begin{array}{l}\text { Utilizing the close relationships that traditional supply chain management } \\
\text { allows, companies seek to develop products together with clients to } \\
\text { improve the products' environmental impact. }\end{array}$ \\
\hline GSCM 10 & $\begin{array}{l}\text { Work with clients to } \\
\text { make production cleaner }\end{array}$ & $\begin{array}{l}\text { Utilizing the close relationships that traditional supply chain management } \\
\text { allows, companies seek to manufacture more cleanly with cooperation } \\
\text { from the client. }\end{array}$ \\
\hline GSCM 11 & $\begin{array}{l}\text { Work with clients to use } \\
\text { environmentally friendly } \\
\text { packaging }\end{array}$ & $\begin{array}{l}\text { Utilizing the close relationships that traditional supply chain management } \\
\text { allows, companies seek to use environmentally friendly packaging with } \\
\text { cooperation from clients. }\end{array}$ \\
\hline GSCM 12 & $\begin{array}{l}\text { Acquisition of the } \\
\text { cleanest technologies by } \\
\text { the company }\end{array}$ & $\begin{array}{l}\text { The company buys equipment that allows it to make products as cleanly as } \\
\text { possible. }\end{array}$ \\
\hline GSCM 13 & $\begin{array}{l}\text { Product designs that } \\
\text { reduce, reuse, recycle, or } \\
\text { reclaim materials, } \\
\text { components, or energy }\end{array}$ & $\begin{array}{l}\text { The company observes policies on material reduction, parts reuse, } \\
\text { recycling of the product after use, and recuperation of materials, } \\
\text { components, or energy throughout the product's life. }\end{array}$ \\
\hline GSCM 14 & $\begin{array}{l}\text { Product designs that } \\
\text { avoid or reduce toxic or } \\
\text { hazardous material use }\end{array}$ & $\begin{array}{l}\text { In developing products, the company incorporates ways to avoid or reduce } \\
\text { the use of dangerous or toxic products. }\end{array}$ \\
\hline GSCM 15 & $\begin{array}{l}\text { Sale of excess stock or } \\
\text { materials }\end{array}$ & The company seeks to sell obsolete stock to recuperate its investment. \\
\hline GSCM 16 & $\begin{array}{l}\text { Sale of scrap and used } \\
\text { materials }\end{array}$ & $\begin{array}{l}\text { The company seeks to sell waste and used materials (i.e., materials that do } \\
\text { not have value in the production line) to recuperate its investment. }\end{array}$ \\
\hline GSCM 17 & $\begin{array}{l}\text { ale of used equipment } \\
\text { (after buying new } \\
\text { equipment) }\end{array}$ & The company sells used equipment to recuperate its investment. \\
\hline
\end{tabular}

Table 1c: Ten top cited article in green supplier selection

\begin{tabular}{|c|c|c|c|c|}
\hline Author(s) & Purpose of Paper & & Supplier Selection Criteria & Method \\
\hline $\begin{array}{l}\text { Min and Galle } \\
(2001)\end{array}$ & $\begin{array}{l}\text { Examine the factors that influence the } \\
\text { complacency of the buyer companies to } \\
\text { adopt green purchasing strategy. }\end{array}$ & 1) & $\begin{array}{l}\text { Environmental liability and } \\
\text { penalty; } \\
\text { A supplier's environmental } \\
\text { commitment } \\
\text { Environmental cost. }\end{array}$ & $\begin{array}{l}\text { Statistics } \\
\text { (hypothesis } \\
\text { testing and } \\
\text { factor } \\
\text { analysis) }\end{array}$ \\
\hline $\begin{array}{l}\text { Lee et al. } \\
(2009)\end{array}$ & $\begin{array}{l}\text { Propose a model for evaluating green } \\
\text { suppliers. It defined a hierarchy to } \\
\text { evaluate the importance of the criteria } \\
\text { for selection of green suppliers. }\end{array}$ & $\begin{array}{l}\text { 1) } \\
\text { 2) } \\
\text { 3) } \\
4) \\
\text { 5) } \\
6 \text { ) }\end{array}$ & $\begin{array}{l}\text { Quality; } \\
\text { Technology capability; } \\
\text { Pollution control; } \\
\text { Environmental management; } \\
\text { Green product; } \\
\text { Green competencies. }\end{array}$ & $\begin{array}{l}\text { Fuzzy, AHP } \\
\text { e Fuzzy } \\
\text { expanded } \\
\text { AHP. }\end{array}$ \\
\hline $\begin{array}{l}\text { Jabbour and } \\
\text { Jabbour (2009) }\end{array}$ & $\begin{array}{l}\text { Verify if Brazilian companies are } \\
\text { adopting environmental requirements } \\
\text { section of suppliers. }\end{array}$ & $\begin{array}{l}\text { 1) } \\
\text { 2) } \\
\text { 3) } \\
\text { 4) } \\
\text { 5) }\end{array}$ & $\begin{array}{l}\text { Cost; } \\
\text { Quality; } \\
\text { Innovation; } \\
\text { Delivery; } \\
\text { Restrictions on the use of } \\
\text { chemicals; } \\
\text { ISO 14001. }\end{array}$ & Case studies \\
\hline $\begin{array}{l}\text { Kuo, Wang, } \\
\text { and Tien } \\
(2010)\end{array}$ & $\begin{array}{l}\text { Develop a selection of green suppliers } \\
\text { using a model that integrates artificial } \\
\text { neural network (ANN), data } \\
\text { envelopment analysis (DEA) and } \\
\text { analytic network process (ANP). }\end{array}$ & $\begin{array}{l}\text { 1) } \\
\text { 2) } \\
\text { 3) } \\
\text { 4) } \\
\text { 5) }\end{array}$ & $\begin{array}{l}\text { Quality; } \\
\text { Service; } \\
\text { Corporate social responsibility; } \\
\text { Delivery; } \\
\text { Cost; } \\
\text { Environment. }\end{array}$ & $\begin{array}{l}\text { ANN, DEA, } \\
\text { ANP. }\end{array}$ \\
\hline $\begin{array}{c}\text { Wolf and } \\
\text { Seuring }(2010)\end{array}$ & $\begin{array}{l}\text { Analyze whether environmental issues } \\
\text { are part of the criteria for selection of }\end{array}$ & 2) & $\begin{array}{l}\text { Cost; } \\
\text { Lead time; }\end{array}$ & Case studies \\
\hline
\end{tabular}




\begin{tabular}{|c|c|c|c|c|}
\hline & logistics service providers. & $\begin{array}{l}\text { 3) } \\
4) \\
5) \\
6)\end{array}$ & $\begin{array}{l}\text { Reliability; } \\
\text { Variety; } \\
\text { Quality; } \\
\text { Environment. }\end{array}$ & \\
\hline $\begin{array}{l}\text { Buyukozkan } \\
\text { and Çifçi } \\
(2011)\end{array}$ & $\begin{array}{l}\text { Identify a model based on principles of } \\
\text { sustainability to select suppliers for } \\
\text { supply chains. }\end{array}$ & $\begin{array}{l}\text { 1) } \\
\text { 2) } \\
\text { 3) } \\
\text { 4) } \\
\text { 5) }\end{array}$ & $\begin{array}{l}\text { Organization; } \\
\text { Financial performance; } \\
\text { Quality; } \\
\text { Technology; } \\
\text { Corporative social and } \\
\text { environmental responsibility. }\end{array}$ & Fuzzy ANP \\
\hline $\begin{array}{l}\text { Buyukozkan } \\
\text { and Çifçi } \\
(2012)\end{array}$ & $\begin{array}{l}\text { Evaluate the selection of green suppliers } \\
\text { for qualitative and quantitative factors. }\end{array}$ & $\begin{array}{l}\text { 1) } \\
\text { 2) } \\
\text { 3) } \\
\text { 4) } \\
\text { 5) }\end{array}$ & $\begin{array}{l}\text { Organization; } \\
\text { Financial performance; } \\
\text { Quality; } \\
\text { Technology; } \\
\text { Corporative social and } \\
\text { environmental responsibility. }\end{array}$ & $\begin{array}{c}\text { Fuzzy } \\
\text { Dematel, } \\
\text { Fuzzy ANP, } \\
\text { Fuzzy } \\
\text { TOPSIS }\end{array}$ \\
\hline $\begin{array}{c}\text { Yeh and } \\
\text { Chuang (2011) }\end{array}$ & $\begin{array}{l}\text { Develop a model for optimal planning } \\
\text { of mathematics to select partners greens. }\end{array}$ & $\begin{array}{l}\text { 1) } \\
\text { 2) } \\
\text { 3) } \\
\text { 4) } \\
\text { 5) }\end{array}$ & $\begin{array}{l}\text { Capability. } \\
\text { Productivity; } \\
\text { Cost; } \\
\text { Quality; } \\
\text { ISO } 14000 .\end{array}$ & $\begin{array}{l}\text { Genetic } \\
\text { algorithm }\end{array}$ \\
\hline $\begin{array}{l}\text { Tseng and } \\
\text { Chiu (2013) }\end{array}$ & $\begin{array}{l}\text { Illustrate a case of a company that aims } \\
\text { to select green suppliers to meet } \\
\text { requirements of GSCM }\end{array}$ & \multicolumn{2}{|c|}{$\begin{array}{l}\text { 18 criteria, among which: } \\
\text { 1) Delivery; } \\
\text { 2) Financial performance; } \\
\text { 3) Relationship; } \\
\text { 4) Quality; } \\
\text { 5) Price; } \\
\text { 6) Green design; } \\
\text { 7) ISO 14000; } \\
\text { 8) Green purchasing; } \\
\text { 9) Cleaner production. }\end{array}$} & $\begin{array}{c}\text { Fuzzy, } \\
\text { MDCM, } \\
\text { Grey theory }\end{array}$ \\
\hline $\begin{array}{l}\text { Shaw et al. } \\
\text { (2012) }\end{array}$ & $\begin{array}{l}\text { Propose an integrative model to select } \\
\text { suppliers for the supply chain } \\
\text { considering carbon emissions. }\end{array}$ & $\begin{array}{l}\text { 1) } \\
\text { 2) } \\
\text { 3) } \\
\text { 4) }\end{array}$ & $\begin{array}{l}\text { Cost; } \\
\text { Quality; } \\
\text { Delivery; } \\
\text { Emissions of greenhouse gases. }\end{array}$ & $\begin{array}{l}\text { Fuzzy-AHP, } \\
\text { Fuzzy multi- } \\
\text { objective } \\
\text { linear } \\
\text { programming }\end{array}$ \\
\hline
\end{tabular}

Table 1d: Fuzzy TOPSIS application area

\begin{tabular}{|l|l|}
\hline Proposed by & Application area \\
\hline Krohling et al., 2011 & Oil spill problem \\
\hline Ding, 2011 & Partner selection of a shipping company \\
\hline Wang and Elhag, 2006 & Bridge risk assessment problem \\
\hline Torlak et al., 2011 & Airline industry \\
\hline Kelemenis et al., 2011 & Manager selection \\
\hline Saremi et al., 2009 & TQM consultant section \\
\hline Singh and Benyoucef, 2011 & e-sourcing \\
\hline Wang et al., 2009 & Supplier selection \\
\hline Dağdeviren et al., 2009 & Weapon selection \\
\hline Kannan et al., 2009 & Reverse logistic provider selection \\
\hline Liao and Kao, 2011 & Supplier selection \\
\hline
\end{tabular}

Table 2: Linguistic variables and fuzzy ratings of the Alternative ( Wang and Elhag, 2006)

\begin{tabular}{|l|l|}
\hline \multicolumn{2}{|l|}{ Linguistic expression for rating alternatives (Green suppliers) } \\
\hline Linguistic expression & Fuzzy numbers \\
\hline
\end{tabular}




\begin{tabular}{|l|l|}
\hline Very Poor (VP) & $(0,0,1)$ \\
\hline Poor $(\mathrm{P})$ & $(0,1,3)$ \\
\hline Medium poor (MP) & $(1,3,5)$ \\
\hline Fair $(\mathrm{F})$ & $(3,5,7)$ \\
\hline Medium Good (MG) & $(5,7,9)$ \\
\hline Good (G) & $(7,9,10)$ \\
\hline Very Good (VG) & $(9,10,10)$ \\
\hline
\end{tabular}

Table 3: Linguistic variables and fuzzy ratings of the criteria (Wang and Elhag, 2006)

\begin{tabular}{|l|l|}
\hline \multicolumn{2}{|l|}{ Linguistic expression for relative importance weight of criteria (GSCM practices) } \\
\hline Linguistic expression & Fuzzy numbers \\
\hline Very Low (VL) & $(0,0.2,0.4)$ \\
\hline Low (L) & $(0.2,0.4,0.5)$ \\
\hline Medium (M) & $(0.4,0.6,0.8)$ \\
\hline High (H) & $(0.6,0.8,1)$ \\
\hline Very High (VH) & $(0.8,0.9,1)$ \\
\hline
\end{tabular}

Table 4: Decision makers preference of the criteria

\begin{tabular}{|l|c|c|c|}
\hline & D1 & D2 & D3 \\
\hline GSCM1 & $\mathrm{VH}$ & $\mathrm{VH}$ & $\mathrm{VH}$ \\
\hline GSCM2 & $\mathrm{H}$ & $\mathrm{H}$ & $\mathrm{VH}$ \\
\hline GSCM3 & $\mathrm{H}$ & $\mathrm{VH}$ & $\mathrm{VH}$ \\
\hline GSCM4 & $\mathrm{VH}$ & $\mathrm{H}$ & $\mathrm{M}$ \\
\hline GSCM5 & $\mathrm{H}$ & $\mathrm{VH}$ & $\mathrm{H}$ \\
\hline GSCM6 & $\mathrm{H}$ & $\mathrm{H}$ & $\mathrm{VH}$ \\
\hline GSCM7 & $\mathrm{H}$ & $\mathrm{H}$ & $\mathrm{M}$ \\
\hline GSCM8 & $\mathrm{H}$ & $\mathrm{M}$ & $\mathrm{M}$ \\
\hline GSCM9 & $\mathrm{VH}$ & $\mathrm{H}$ & $\mathrm{H}$ \\
\hline GSCM10 & $\mathrm{H}$ & $\mathrm{M}$ & $\mathrm{M}$ \\
\hline GSCM11 & $\mathrm{H}$ & $\mathrm{H}$ & $\mathrm{H}$ \\
\hline GSCM12 & $\mathrm{H}$ & $\mathrm{H}$ & $\mathrm{VH}$ \\
\hline GSCM13 & $\mathrm{VH}$ & $\mathrm{VH}$ & $\mathrm{VH}$ \\
\hline GSCM14 & $\mathrm{VH}$ & $\mathrm{H}$ & $\mathrm{VH}$ \\
\hline GSCM15 & $\mathrm{H}$ & $\mathrm{M}$ & $\mathrm{M}$ \\
\hline GSCM16 & $\mathrm{H}$ & $\mathrm{M}$ & $\mathrm{L}$ \\
\hline GSCM17 & $\mathrm{H}$ & $\mathrm{M}$ & $\mathrm{VL}$ \\
\hline
\end{tabular}

Table 5a: Decision maker 1 (DM1) ratings of the alternatives

\begin{tabular}{|l|l|l|l|l|l|l|l|l|l|l|l|l|l|l|l|l|l|}
\hline & C1 & C2 & C3 & C4 & C5 & C6 & C7 & C8 & C9 & C10 & C11 & C12 & C13 & C14 & C15 & C16 & C17 \\
\hline A1 & P & MP & VP & VP & VP & P & P & MP & MP & MP & P & P & P & VP & VP & F & F \\
\hline A2 & P & MG & VG & VP & VP & P & P & MP & F & F & P & MP & G & VG & F & VG & VG \\
\hline
\end{tabular}




\begin{tabular}{|l|l|l|l|l|l|l|l|l|l|l|l|l|l|l|l|l|l|} 
A3 & G & G & VG & VG & G & G & G & MG & MG & MG & VG & VG & VG & VG & G & VG & VG \\
\hline A4 & VG & G & VG & VG & VG & G & VG & MG & G & G & MP & G & G & VG & F & VG & VG \\
\hline A5 & VG & VG & VG & G & VG & VG & VG & G & G & G & F & G & VG & VG & VG & VG & VG \\
\hline A6 & P & MP & MP & VP & VP & P & P & MP & MP & MP & P & P & VP & F & F & F & F \\
\hline A7 & G & G & G & P & VP & MG & P & MP & MG & G & MP & MP & G & F & P & G & G \\
\hline A8 & VP & G & MP & VP & VP & P & P & MP & MP & MP & P & F & F & F & F & F & F \\
\hline A9 & P & MG & VP & F & VP & P & MG & MG & MP & MP & P & F & F & F & VP & G & F \\
\hline A10 & VG & VG & VG & VG & VG & VG & VG & VG & VG & VG & VG & VG & VG & VG & VP & VG & VG \\
\hline A11 & G & G & VG & VG & G & F & MG & MG & MP & MP & MP & MP & F & VG & VG & VG & VG \\
\hline A12 & VG & G & G & VG & G & G & G & G & G & G & G & G & G & G & F & F & F \\
\hline
\end{tabular}

Table 5b: Decision maker 2 (DM2) ratings of the alternatives

\begin{tabular}{|l|l|l|l|l|l|l|l|l|l|l|l|l|l|l|l|l|l|}
\hline & C1 & C2 & C3 & C4 & C5 & C6 & C7 & C8 & C9 & C10 & C11 & C12 & C13 & C14 & C15 & C16 & C17 \\
\hline A1 & F & F & VP & VP & P & P & VP & MP & P & VP & VP & VP & P & VP & P & F & F \\
\hline A2 & F & MG & VG & VP & P & P & VP & MP & P & P & VP & VP & G & VG & MG & VG & VG \\
\hline A3 & G & G & VG & VG & VG & G & MG & MG & F & F & VG & VG & VG & VG & F & VG & VG \\
\hline A4 & VG & F & VG & VG & VG & G & VG & MG & MG & F & P & G & G & VG & MG & VG & VG \\
\hline A5 & VG & MG & F & G & VG & VG & VG & G & MG & VP & F & G & VG & VG & VG & VG & VG \\
\hline A6 & P & F & G & VP & P & P & P & MP & P & MG & VP & VP & P & MG & MG & F & VP \\
\hline A7 & G & G & G & P & P & MG & P & MP & F & VP & P & MP & G & MG & P & MG & G \\
\hline A8 & P & G & F & VP & P & P & P & MP & P & VP & VP & F & MG & MG & P & F & MG \\
\hline A9 & F & G & VP & F & P & P & F & MG & P & VG & VP & F & MG & MG & VP & MG & MG \\
\hline A10 & G & MG & VG & VG & VG & G & VG & VG & G & VP & G & VG & VG & VG & VP & VG & VG \\
\hline A11 & G & G & VG & VG & VG & P & F & F & P & VP & MP & F & MG & VG & VG & VG & VG \\
\hline A12 & VG & G & G & VG & VG & VG & MG & MG & F & G & VG & VG & G & G & F & G & MG \\
\hline
\end{tabular}

Table 5c: Decision maker 3 (DM3) ratings of the alternatives

\begin{tabular}{|l|l|l|l|l|l|l|l|l|l|l|l|l|l|l|l|l|l|}
\hline & C1 & C2 & C3 & C4 & C5 & C6 & C7 & C8 & C9 & C10 & C11 & C12 & C13 & C14 & C15 & C16 & C17 \\
\hline A1 & P & P & VP & VP & VP & VP & VP & VP & VP & VP & VP & VP & P & VP & VP & G & G \\
\hline A2 & P & MP & VG & VP & VP & VP & VP & VP & MP & F & VP & P & MG & VG & MG & VG & VG \\
\hline A3 & MG & MG & VG & VG & G & MG & G & MG & F & MG & VG & VG & VG & VG & G & VG & VG \\
\hline A4 & VG & MG & VG & VG & VG & MG & VG & MG & G & G & MP & MG & MG & VG & MG & VG & VG \\
\hline A5 & VG & VG & VG & G & VG & VG & VG & G & G & G & F & MG & VG & VG & VG & VG & VG \\
\hline A6 & P & P & MP & VP & VP & VP & VP & VP & VP & VP & VP & VP & VP & MP & MG & G & VP \\
\hline A7 & MG & MG & MG & F & VP & MP & VP & VP & F & G & MP & P & MG & MP & F & G & VG \\
\hline A8 & VP & MG & MP & VP & VP & VP & VP & VP & VP & VP & VP & MP & MP & MP & MG & G & G \\
\hline A9 & P & MP & VP & MG & VP & VP & MG & MG & VP & VP & VP & MP & MP & MP & VP & G & G \\
\hline A10 & VG & VG & VG & VG & VG & VG & VG & VG & VG & VG & VG & VG & VG & VG & VP & VG & VG \\
\hline A11 & MG & MG & VG & VG & G & P & MG & MG & VP & VP & MP & P & MP & VG & VG & VG & VG \\
\hline A12 & VG & MG & MG & VG & G & MG & G & G & G & G & G & MG & MG & MG & MG & G & G \\
\hline
\end{tabular}


Table 6: Calculated fuzzy aggregated weights of each criterion

\begin{tabular}{|l|l|}
\hline C1 & $(0.8,0.9,1)$ \\
\hline C2 & $(0.6,0.833, \quad 1)$ \\
\hline C3 & $(0.6,0.867,1)$ \\
\hline C4 & $(0.4,0.767, \quad 1)$ \\
\hline C5 & $(0.6,0.833, \quad 1)$ \\
\hline C6 & $(0.6,0.833, \quad 1)$ \\
\hline C7 & $(0.4,0.733, \quad 1)$ \\
\hline C8 & $(0.4,0.667, \quad 1)$ \\
\hline C9 & $(0.6,0.833,1)$ \\
\hline C10 & $(0.4,0.667, \quad 1)$ \\
\hline C11 & $(0.6,0.833, \quad 1)$ \\
\hline C12 & $(0.8,0.9,1)$ \\
\hline C13 & $(0.4,0.667, \quad 1)$ \\
\hline C14 & $(0.2,0.6,1)$ \\
\hline C15 & $(0,0.533,1)$ \\
\hline C16 & \\
\hline C17 & \\
\hline
\end{tabular}

Table 9: Distance

\begin{tabular}{|c|c|c|}
\hline & D+ solutions & D-solutions \\
\hline $\mathbf{A 1}$ & 13.6 & 4.14 \\
\hline $\mathbf{A 2}$ & 11 & 7.19 \\
\hline $\mathbf{A 3}$ & 7.02 & 11.5 \\
\hline $\mathbf{A 4}$ & 7.3 & 11.1 \\
\hline $\mathbf{A 5}$ & 6.75 & 11.7 \\
\hline $\mathbf{A 6}$ & 12.8 & 5.44 \\
\hline $\mathbf{A 7}$ & 10.3 & 8.39 \\
\hline $\mathbf{A 8}$ & 12.4 & 5.88 \\
\hline $\mathbf{A 9}$ & 11.8 & 6.75 \\
\hline $\mathbf{A 1 0}$ & 6.77 & 11.4 \\
\hline $\mathbf{A 1 1}$ & 8.71 & 9.75 \\
\hline $\mathbf{A 1 2}$ & 7.38 & 11.4 \\
\hline
\end{tabular}

Table 14: Ranking of criterion weights

\begin{tabular}{|c|c|c|}
\hline Criterion & Weights & $\begin{array}{l}\text { Rankin } \\
\text { g }\end{array}$ \\
\hline C1 & $(0.8,0.9, \quad 1)$ & 1 \\
\hline C2 & $(0.6,0.833, \quad 1)$ & 3 \\
\hline C3 & $(\mathbf{0 . 6 , 0 . 8 6 7 ,}, \mathbf{1})$ & $\mathbf{2}$ \\
\hline C4 & $(0.4,0.767, \quad 1)$ & 5 \\
\hline C5 & $(0.6,0.833, \quad 1)$ & 3 \\
\hline C6 & $(0.6,0.833, \quad 1)$ & 3 \\
\hline C7 & $(0.4,0.733, \quad 1)$ & 6 \\
\hline C8 & $(0.4,0.667, \quad 1)$ & 7 \\
\hline C9 & $(0.6,0.833, \quad 1)$ & 3 \\
\hline C10 & $(0.4,0.667, \quad 1)$ & 7 \\
\hline C11 & $(0.6,0.8, \quad 1)$ & 4 \\
\hline C12 & $(0.6,0.833, \quad 1)$ & 3 \\
\hline C13 & $(0.8,0.9, \quad 1)$ & 1 \\
\hline C14 & $(\mathbf{0 . 6 , 0 . 8 6 7 ,} \quad \mathbf{1})$ & $\mathbf{2}$ \\
\hline C15 & $(0.4,0.667, \quad 1)$ & 7 \\
\hline C16 & $(0.2,0.6, \quad 1)$ & 8 \\
\hline C17 & $(0,0.533, \quad 1)$ & 9 \\
\hline
\end{tabular}


Table 7: Calculated fuzzy aggregated decision matrix

\begin{tabular}{|c|c|c|c|c|c|c|c|c|}
\hline & C1 & $\mathrm{C2}$ & $\mathrm{C3}$ & C4 & C5 & C6 & C7 & C8 \\
\hline A1 & $(0,2.33,7)$ & $(0,3,7)$ & $\left(\begin{array}{lll}0, & 0, & 1) \\
\end{array}\right.$ & $\left(\begin{array}{lll}0, & 0, & 1\end{array}\right)$ & $(0,0.333,3)$ & $(0,0.667,3)$ & $(0,0.333,3)$ & $(0,2,5)$ \\
\hline A2 & $(0,2.33,7)$ & $(1,5.67,9)$ & $(9,10,10)$ & $\left(\begin{array}{lll}0, & 0, & 1)\end{array}\right.$ & $(0,0.333,3)$ & $(0,0.667,3)$ & $(0,0.333,3)$ & $(0,2,5)$ \\
\hline $\mathbf{A 3}$ & $(5,8.33,10)$ & $(5,8.33,10)$ & $(9,10,10)$ & $(9,10,10)$ & $(7,9.33,10)$ & $(5,8.33,10)$ & $(5,8.33,10)$ & $(5,7,9)$ \\
\hline A4 & $(9,10,10)$ & $(3,7,10)$ & $(9,10,10)$ & $(9,10,10)$ & $(9,10,10)$ & $(5,8.33,10)$ & $(9,10,10)$ & $(5,7,9)$ \\
\hline A5 & $(9,10,10)$ & $(5,9,10)$ & $(3,8.33,10)$ & $(7,9,10)$ & $(9,10,10)$ & $(9,10,10)$ & $(9,10,10)$ & $(7,9,10)$ \\
\hline A6 & $\left(\begin{array}{lll}0, & 1, & 3\end{array}\right)$ & $(0,3,7)$ & $(1, \quad 5,10)$ & $\left(\begin{array}{lll}0, & 0, & 1)\end{array}\right.$ & $(0,0.333,3)$ & $(0,0.667,3)$ & $(0,0.667,3)$ & $\left(\begin{array}{lll}0, & 2, & 5\end{array}\right)$ \\
\hline A7 & $(5,8.33,10)$ & $(5,8.33,10)$ & $(5,8.33,10)$ & $(0,2.33,7)$ & $(0,0.333,3)$ & $(1,5.67,9)$ & $(0,0.667,3)$ & $\left(\begin{array}{lll}0, & 2, & 5\end{array}\right)$ \\
\hline A8 & $(0,0.333,3)$ & $(5,8.33,10)$ & $(1,3.67,7)$ & $(0,0,1)$ & $(0,0.333,3)$ & $(0,0.667,3)$ & $(0,0.667,3)$ & $(0,2,5)$ \\
\hline A9 & $(0,2.33,7)$ & $(1,6.33,10)$ & $\left(\begin{array}{lll}0, & 0, & 1\end{array}\right)$ & $(3,5.67,9)$ & $(0,0.333,3)$ & $(0,0.667,3)$ & $(3,6.33,9)$ & $(5,7,9)$ \\
\hline A10 & $(7,9.67,10)$ & $(5,9,10)$ & $(9,10,10)$ & $(9,10,10)$ & $(9,10,10)$ & $(7,9.67,10)$ & $(9,10,10)$ & $(9,10,10)$ \\
\hline A11 & $(5,8.33,10)$ & $(5,8.33,10)$ & $(9,10,10)$ & $(9,10,10)$ & $(7,9.33,10)$ & $(0,2.33,7)$ & $(3,6.33,9)$ & $(3,6.33,9)$ \\
\hline A12 & $(9,10,10)$ & $(5,8.33,10)$ & $(5,8.33,10)$ & $(9,10,10)$ & $(7,9.33,10)$ & $(5,8.67,10)$ & $(5,8.33,10)$ & $(5,8.33,10)$ \\
\hline
\end{tabular}

\begin{tabular}{|c|c|c|c|c|c|c|c|c|c|}
\hline & C9 & C10 & C11 & C12 & C13 & C14 & C15 & C16 & C17 \\
\hline A1 & $(0,1.33,5)$ & $(0,1, \quad 5)$ & $(0,0.333,3)$ & $(0,0.333,3)$ & $(0,1,3)$ & $\left(\begin{array}{lll}0, & 0,1)\end{array}\right.$ & $(0,0.333,3)$ & $(3,6.33,10)$ & $(3,6.33,10)$ \\
\hline A2 & $(0,3,7)$ & $(0,3.67,7)$ & $(0,0.333,3)$ & $(0,1.33,5)$ & $(5,8.33,10)$ & $(9,10,10)$ & $(3,6.33,9)$ & $(9,10,10)$ & $(9,10,10)$ \\
\hline $\mathbf{A 3}$ & $(3,5.67,9)$ & $(3,6.33,9)$ & $(9,10,10)$ & $(9,10,10)$ & $(9,10,10)$ & $(9,10,10)$ & $(3,7.67,10)$ & $(9,10,10)$ & $(9,10,10)$ \\
\hline A4 & $(5,8.33,10)$ & $(3,7.67,10)$ & $(0,2.33,5)$ & $(5,8.33,10)$ & $(5,8.33,10)$ & $(9,10,10)$ & $(3,6.33,9)$ & $(9,10,10)$ & $(9,10,10)$ \\
\hline A6 & $(0,1.33,5)$ & $(0,3.33,9)$ & $(0,0.333,3)$ & $(0,0.333$, & $(0,0.333$, & $\left(\begin{array}{lll}1, & 5, & 9\end{array}\right.$ & $(3,6.33$, & $(3,6.33,10)$ & $(0,1.67,7)$ \\
\hline A7 & $(3,5.67,9)$ & $(0,6,10)$ & $(0,2.33,5)$ & $(0,2.33,5)$ & $(5,8.33,10)$ & $(1,5,9)$ & $(0,2.33,7)$ & $(5,8.33,10)$ & $(7,9.33,10)$ \\
\hline $\mathrm{A8}$ & $(0,1.33,5)$ & $(0,1,5)$ & $(0,0.333,3)$ & $(1,4.33,7)$ & $(1,5,9)$ & $(1,5,9)$ & $(0,4.33,9)$ & $(3,6.33,10)$ & $(3,7,10)$ \\
\hline A9 & $(0,1.33,5)$ & $(0,4.33,10)$ & $(0,0.333,3)$ & $(1,4.33,7)$ & $(1,5,9)$ & $(1,5,9)$ & $\left(\begin{array}{lll}0, & 0, & 1)\end{array}\right.$ & $(5,8.33,10)$ & $(3,7,10)$ \\
\hline A10 & $(7,9.67,10)$ & $(0,6.67,10)$ & $(7,9.67,10)$ & $(9,10,10)$ & $(9,10,10)$ & $(9, \quad 10,10)$ & $\left(\begin{array}{lll}0, & 0, & 1\end{array}\right)$ & $(9,10,10)$ & $(9,10,10)$ \\
\hline A11 & $(0,1.33,5)$ & $\left(\begin{array}{lll}0, & 1, & 5\end{array}\right)$ & $(1,3,5)$ & $(0,3,7)$ & $(1,5,9)$ & $(9,10,10)$ & $(9,10,10)$ & $(9,10,10)$ & $(9,10,10)$ \\
\hline A12 & $(3,7.67,10)$ & $(7,9,10)$ & $(7,9.33,10)$ & $(5,8.67,10)$ & $(5,8.33,10)$ & $(5,8.33,10)$ & $(3,5.67,9)$ & $(3,7.67,10)$ & $(3, \quad 7,10)$ \\
\hline
\end{tabular}

Table 8: Normalized matrix

\begin{tabular}{|c|c|c|c|c|c|c|c|c|c|}
\hline & C1 & C2 & $\mathrm{C3}$ & $\mathrm{C4}$ & C5 & C6 & C7 & C8 & C9 \\
\hline A1 & $(0,0.233,0.7)$ & $(0,0.3,0.7)$ & $\left(\begin{array}{lll}0, & 0, & 0.1)\end{array}\right.$ & $\left(\begin{array}{lll}0, & 0, & 0.1) \\
\end{array}\right.$ & $(0,0.0333,0.3)$ & $(0,0.0667,0.3)$ & $(0,0.0333,0.3)$ & $(0,0.2,0.5)$ & $(0,0.133,0.5)$ \\
\hline A2 & $(0,0.233,0.7)$ & $(0.1,0.567,0.9)$ & $(0.9,1,1)$ & $(0,0,0.1)$ & $(0,0.0333,0.3)$ & $(0,0.0667,0.3)$ & $(0,0.0333,0.3)$ & $(0,0.2,0.5)$ & $(0,0.3,0.7)$ \\
\hline $\mathbf{A 3}$ & $(0.5,0.833,1)$ & $(0.5,0.833,1)$ & $(0.9,1,1)$ & $(0.9,1,1)$ & $(0.7,0.933,1)$ & $(0.5,0.833,1)$ & $(0.5,0.833,1)$ & $(0.5,0.7,0.9)$ & $(0.3,0.567,0.9)$ \\
\hline A4 & $(0.9,1,1)$ & $(0.3,0.7,1)$ & $(0.9,1,1)$ & $(0.9,1,1)$ & $(0.9,1,1)$ & $(0.5,0.833,1)$ & $(0.9,1,1)$ & $(0.5,0.7,0.9)$ & $(0.5,0.833,1)$ \\
\hline A5 & $\left(\begin{array}{lll}0.9, & 1, & 1\end{array}\right)$ & $(0.5,0.9,1)$ & $(0.3,0.833,1)$ & $(0.7,0.9,1)$ & $(0.9,1,1)$ & $\left(\begin{array}{lll}0.9, & 1, & 1)\end{array}\right.$ & $(0.9,1,1)$ & $(0.7,0.9,1)$ & $(0.5,0.833,1)$ \\
\hline A6 & $(0,0.1,0.3)$ & $(0,0.3,0.7)$ & $(0.1,0.5,1)$ & $\left(\begin{array}{lll}0, & 0,0.1)\end{array}\right.$ & $(0,0.0333,0.3)$ & $(0,0.0667,0.3)$ & $(0,0.0667,0.3)$ & $(0,0.2,0.5)$ & $(0,0.133,0.5)$ \\
\hline A7 & $(0.5,0.833,1)$ & $(0.5,0.833,1)$ & $(0.5,0.833,1)$ & $(0,0.233,0.7)$ & $(0,0.0333,0.3)$ & $(0.1,0.567,0.9)$ & $(0,0.0667,0.3)$ & $(0,0.2,0.5)$ & $(0.3,0.567,0.9)$ \\
\hline A8 & $(0,0.0333,0.3)$ & $(0.5,0.833,1)$ & $(0.1,0.367,0.7)$ & $\left(\begin{array}{lll}0, & 0,0.1)\end{array}\right.$ & $(0,0.0333,0.3)$ & $(\quad 0,0.0667,0.3)$ & $(0,0.0667,0.3)$ & $(0,0.2,0.5)$ & $(0,0.133,0.5)$ \\
\hline A9 & $(0,0.233,0.7)$ & $(0.1,0.633,1)$ & $\left(\begin{array}{lll}0, & 0,1)\end{array}\right.$ & $(0.3,0.567,0.9)$ & $(0,0.0333,0.3)$ & $(0,0.0667,0.3)$ & $(0.3,0.633,0.9)$ & $(0.5,0.7,0.9)$ & $(0,0.133,0.5)$ \\
\hline A10 & $(0.7,0.967,1)$ & $(0.5,0.9,1)$ & $(0.9,1,1)$ & $(0.9,1,1)$ & $(0.9,1,1)$ & $(0.7,0.967,1)$ & $(0.9,1,1)$ & $(0.9,1,1)$ & $(0.7,0.967,1)$ \\
\hline A11 & $(0.5,0.833,1)$ & $(0.5,0.833,1)$ & $(0.9,1,1)$ & $(0.9,1,1)$ & $(0.7,0.933,1)$ & $(0,0.233,0.7)$ & $(0.3,0.633,0.9)$ & $(0.3,0.633,0.9)$ & $3,0.5)$ \\
\hline $\mathbf{A 1 2}$ & $\left(\begin{array}{lll}0.9, & 1, & 1\end{array}\right)$ & $(0.5,0.833,1)$ & $(0.5,0.833,1)$ & $\left(\begin{array}{lll}0.9, & 1, & 1\end{array}\right)$ & $(0.7,0.933,1)$ & $\left(\begin{array}{lll}0.5,0.867, & 1)\end{array}\right.$ & $(0.5,0.833,1)$ & $(0.5,0.833,1)$ & $(0.3,0.767,1)$ \\
\hline
\end{tabular}




\begin{tabular}{|c|c|c|c|c|c|c|c|c|}
\hline & C10 & C11 & $\mathrm{C} 12$ & C13 & C14 & $\mathrm{C} 15$ & C16 & C17 \\
\hline A1 & $(0,0.1,0.5)$ & $(0,0.0333,0.3)$ & $\left(\begin{array}{lll}0, & 0, & 0\end{array}\right)$ & $(0,0.1,0.3)$ & $\left(\begin{array}{lll}0, & 0,1) \\
\end{array}\right.$ & $(0,0.0333,0.3)$ & $(0.3,0.633,1)$ & $(0.3,0.633,1)$ \\
\hline A2 & $(0,0.367,0.7)$ & $(0,0.0333,0.3)$ & $\left(\begin{array}{lll}0, & 0, & 0\end{array}\right)$ & $(0.5,0.833,1)$ & $(0.9,1, \quad 1)$ & $(0.3,0.633,0.9)$ & $(0.9,1,1)$ & $(0.9,1,1)$ \\
\hline A3 & $(0.3,0.633,0.9)$ & $(0.9,1,1)$ & $\left(\begin{array}{lll}0, & 0, & 0\end{array}\right)$ & $\left(\begin{array}{lll}0.9, & 1, & 1\end{array}\right)$ & $(0.9,1,1)$ & $(0.3,0.767,1)$ & $(0.9,1,1)$ & $(0.9,1,1)$ \\
\hline A4 & $(0.3,0.767,1)$ & $(0,0.233,0.5)$ & $\left(\begin{array}{lll}0, & 0, & 0\end{array}\right)$ & $(0.5,0.833,1)$ & $(0.9,1,1)$ & $(0.3,0.633,0.9)$ & $(0.9,1,1)$ & $(0.9,1,1)$ \\
\hline A5 & $\left(\begin{array}{lll}0, & 0.6, & 1\end{array}\right)$ & $(0.3,0.5,0.7)$ & $\left(\begin{array}{lll}0, & 0, & 0\end{array}\right)$ & $\left(\begin{array}{lll}0.9, & 1, & 1\end{array}\right)$ & $\left(\begin{array}{lll}0.9, & 1, & 1\end{array}\right)$ & $\left(\begin{array}{lll}0.9, & 1, & 1\end{array}\right)$ & $\left(\begin{array}{lll}0.9, & 1, & 1\end{array}\right)$ & $\left(\begin{array}{lll}0.9, & 1, & 1\end{array}\right)$ \\
\hline A6 & $(0,0.333,0.9)$ & $(0,0.0333,0.3)$ & $\left(\begin{array}{lll}0, & 0, & 0\end{array}\right)$ & $(0,0.0333,0.3)$ & $(0.1,0.5,0.9)$ & $(0.3,0.633,0.9)$ & $(0.3,0.633,1)$ & $(0,0.167,0.7)$ \\
\hline A7 & $(0,0.6,1)$ & $(0,0.233,0.5)$ & $\left(\begin{array}{lll}0, & 0, & 0\end{array}\right)$ & $(0.5,0.833,1)$ & $(0.1,0.5,0.9)$ & $(0,0.233,0.7)$ & $(0.5,0.833,1)$ & $(0.7,0.933,1)$ \\
\hline A8 & $(0,0.1,0.5)$ & $(0,0.0333,0.3)$ & $\left(\begin{array}{lll}0, & 0, & 0\end{array}\right)$ & $(0.1,0.5,0.9)$ & $(0.1,0.5,0.9)$ & $(0,0.433,0.9)$ & $(0.3,0.633,1)$ & $(0.3,0.7,1)$ \\
\hline A9 & $(0,0.433,1)$ & $(0,0.0333,0.3)$ & $\left(\begin{array}{lll}0, & 0, & 0\end{array}\right)$ & $(0.1,0.5,0.9)$ & $(0.1,0.5,0.9)$ & $\left(\begin{array}{lll}0, & 0,0.1)\end{array}\right.$ & $(0.5,0.833,1)$ & $(0.3,0.7,1)$ \\
\hline A10 & $(0,0.667,1)$ & $(0.7,0.967,1)$ & $\left(\begin{array}{lll}0, & 0, & 0\end{array}\right)$ & $(0.9,1,1)$ & $(0.9,1,1)$ & $(0,0,0.1)$ & $(0.9,1,1)$ & $(0.9,1,1)$ \\
\hline A11 & $(0,0.1,0.5)$ & $(0.1,0.3,0.5)$ & $\left(\begin{array}{lll}0, & 0, & 0\end{array}\right)$ & $(0.1,0.5,0.9)$ & $(0.9,1,1)$ & $(0.9,1,1)$ & $(0.9,1,1)$ & $(0.9,1, \quad 1)$ \\
\hline A12 & $(0.7,0.9,1)$ & $(0.7,0.933,1)$ & $\left(\begin{array}{lll}0, & 0, & 0\end{array}\right)$ & $(0.5,0.833,1)$ & $(0.5,0.833,1)$ & $(0.3,0.567,0.9)$ & $(0.3,0.767,1)$ & $(0.3,0.7,1)$ \\
\hline
\end{tabular}

Table 10: Closeness coefficient

\begin{tabular}{|c|c|}
\hline $\mathbf{A 1}$ & 0.234 \\
\hline $\mathbf{A 2}$ & 0.396 \\
\hline $\mathbf{A 3}$ & 0.62 \\
\hline $\mathbf{A 4}$ & 0.604 \\
\hline $\mathbf{A 5}$ & 0.634 \\
\hline $\mathbf{A 6}$ & 0.298 \\
\hline $\mathbf{A} 7$ & 0.448 \\
\hline $\mathbf{A 8}$ & 0.322 \\
\hline $\mathbf{A 9}$ & 0.364 \\
\hline $\mathbf{A 1 0}$ & 0.628 \\
\hline $\mathbf{A 1 1}$ & 0.528 \\
\hline $\mathbf{A 1}$ & 0.606 \\
\hline
\end{tabular}

\section{Table 11: Rank}

\begin{tabular}{|c|c|}
\hline $\mathbf{A 1}$ & 12 \\
\hline $\mathbf{A 2}$ & 8 \\
\hline $\mathbf{A 3}$ & 3 \\
\hline $\mathbf{A 4}$ & 5 \\
\hline $\mathbf{A 5}$ & 1 \\
\hline $\mathbf{A 6}$ & 11 \\
\hline $\mathbf{A} 7$ & 7 \\
\hline $\mathbf{A 8}$ & 10 \\
\hline $\mathbf{A 9}$ & 9 \\
\hline $\mathbf{A 1 0}$ & 2 \\
\hline $\mathbf{A 1 1}$ & 6 \\
\hline $\mathbf{A 1 2}$ & 4 \\
\hline
\end{tabular}

Table 12: Final Ranks of the different Fuzzy TOPSIS approaches:

\begin{tabular}{|c|c|c|c|}
\hline & Graded & GeoM & MAM \\
\hline A1 & 12 & 12 & 12 \\
\hline $\mathbf{A 2}$ & 8 & 8 & 8 \\
\hline $\mathbf{A 3}$ & 2 & 3 & 3 \\
\hline $\mathbf{A 4}$ & 5 & 5 & 5 \\
\hline $\mathbf{A 5}$ & 3 & 2 & 1 \\
\hline $\mathbf{A 6}$ & 11 & 11 & 11 \\
\hline $\mathbf{A 7}$ & 7 & 7 & 7 \\
\hline $\mathbf{A 8}$ & 10 & 10 & 10 \\
\hline $\mathbf{A 9}$ & 9 & 9 & 9 \\
\hline $\mathbf{A 1 0}$ & 4 & 1 & 2 \\
\hline $\mathbf{A 1 1}$ & 6 & 6 & 6 \\
\hline A12 & 1 & 4 & 4 \\
\hline
\end{tabular}


Table 13: Spearman correlation co-efficient (R)

\begin{tabular}{|l|c|c|c|}
\hline & $\begin{array}{c}\text { Proposed Fuzzy } \\
\text { TOPSIS }\end{array}$ & $\begin{array}{c}\text { Geometric mean based } \\
\text { fuzzy TOPSIS }\end{array}$ & $\begin{array}{c}\text { Graded mean } \\
\text { integration fuzzy } \\
\text { TOPSIS }\end{array}$ \\
\hline Proposed Fuzzy TOPSIS & 1 & 0.993007 & 0.937063 \\
\hline Geometric mean based fuzzy TOPSIS & & 1 & 0.93007 \\
\hline Graded mean integration fuzzy TOPSIS & & & 1 \\
\hline
\end{tabular}

Table 15: Details for sensitivity analysis

\begin{tabular}{|c|c|}
\hline Case & $\begin{array}{c}\text { Description } \\
\left.\text { (changes made in } \mathbf{W}_{\mathrm{jt}}\right) \\
\mathrm{J}=\mathrm{C} 1, \mathrm{C} 2, \ldots, \mathrm{C} 17 \\
\mathrm{t}=1,2,3\end{array}$ \\
\hline Case 1 & $\mathbf{W}_{\mathbf{c 1 t}}=(0,0.2,0.4),{ }^{\mathbf{1}} \mathbf{W}_{\mathbf{c 2 t - c 1 7 t}}$ \\
\hline Case 2 & $\mathbf{W}_{\mathbf{c 1 t}}=(0.2,0.4,0.5),{ }^{1} \mathbf{W}_{\mathbf{c 2 t} \mathbf{c} 17 \mathbf{t}}$ \\
\hline Case 3 & $\mathbf{W}_{\mathbf{c 1 t}}=(0.4,0.6,0.8),{ }^{1} \mathbf{W}_{\mathbf{c 2 t - c 1 7 t}}$ \\
\hline Case 4 & $\mathbf{W}_{\mathbf{c 1 t}}=(0.6,0.8,1),{ }^{1} \mathbf{W}_{\mathbf{c} 2 \mathbf{t}-\mathbf{c} 17 \mathbf{t}}$ \\
\hline Case 5 & $\mathbf{W}_{\mathbf{c 1 t}}=(0.8,0.9,1),{ }^{\mathbf{1}} \mathbf{W}_{\mathbf{c 2 t - c 1 7 t}}$ \\
\hline Case 6 & $\mathbf{W}_{\mathbf{c 1 3 t}}=(0,0.2,0.4),{ }^{1} \mathbf{W}_{\mathbf{c 1 t}-\mathbf{c} 12 \mathrm{t}, \mathbf{c 1 4 t - c 1 7 t}}$ \\
\hline Case 7 & $\mathbf{W}_{\mathbf{c 1 3 t}}=(0.2,0.4,0.5),{ }^{1} \mathbf{W}_{\mathbf{c 1 t - c 1 2 t}, \mathbf{c 1 4 t - c 1 7 t}}$ \\
\hline Case 8 & $\mathbf{W}_{\mathbf{c 1 3 t}}=(0.4,0.6,0.8),{ }^{1} \mathbf{W}_{\mathbf{c 1 t - c 1 2 t}, \mathbf{c 1 4 t - c 1 7 t}}$ \\
\hline Case 9 & $\mathbf{W}_{\mathbf{c 1 3 t}}=(0.6,0.8,1),{ }^{1} \mathbf{W}_{\mathbf{c 1 t - c 1 2 t}, \mathbf{c 1 4 t - c 1 7 t}}$ \\
\hline Case 10 & $\mathbf{W}_{\mathbf{c 1 3 t}}=(0.8,0.9,1),{ }^{1} \mathbf{W}_{\mathbf{c 1 t - c 1 2 t}, \mathbf{c 1 4 t - c 1 7 t}}$ \\
\hline Case 11 & $\mathbf{W}_{\mathbf{c 3 t}}=(0,0.2,0.4),{ }^{1} \mathbf{W}_{\mathbf{c 1 t - c 2 t}, \mathbf{c 4 t - c 1 7 t}}$ \\
\hline Case 12 & $\mathbf{W}_{\mathbf{c 3 t}}=(0.2,0.4,0.5),{ }^{1} \mathbf{W}_{\mathbf{c 1 t - c 2 t}, \mathbf{c 4 t}-\mathbf{c 1 7 t}}$ \\
\hline Case 13 & $\mathbf{W}_{\mathrm{c} 3 \mathrm{t}}=(0.4,0.6,0.8),{ }^{\mathbf{1}} \mathbf{W}_{\mathrm{c1t}-\mathrm{c} 2 \mathrm{t}, \mathrm{c4t-c17t}}$ \\
\hline Case 14 & $\mathbf{W}_{\mathbf{c} 3 t}=(0.6,0.8,1),{ }^{1} \mathbf{W}_{\mathbf{c 1 t - c 2 t}, \mathbf{c 4 t - c 1 7 t}}$ \\
\hline Case 15 & $\mathbf{W}_{\mathbf{c 3 t}}=(0.8,0.9,1),{ }^{1} \mathbf{W}_{\mathbf{c 1 t}-\mathbf{c} 2 t, \mathbf{c} 4 t-\mathbf{c} 17 t}$ \\
\hline Case 16 & $\mathbf{W}_{\mathbf{c 1 4 t}}=(0,0.2,0.4),{ }^{1} \mathbf{W}_{\mathbf{c 1 t - c 1 3 t}, \mathbf{c 1 5 t - c 1 7 t}}$ \\
\hline Case 17 & $\mathbf{W}_{\mathbf{c 1 4 t}}=(0.2,0.4,0.5),{ }^{1} \mathbf{W}_{\mathbf{c 1 t - c 1 3 t}, \mathbf{c 1 5 t - c 1 7 t}}$ \\
\hline Case 18 & $\mathbf{W}_{\mathbf{c 1 4 t}}=(0.4,0.6,0.8),{ }^{1} \mathbf{W}_{\mathbf{c 1 t - c 1 3 t}, \mathbf{c 1 5 t - c 1 7 t}}$ \\
\hline Case 19 & $\mathbf{W}_{\mathbf{c 1 4 t}}=(0.6,0.8,1),{ }^{1} \mathbf{W}_{\mathbf{c 1 t - c 1 3 t}, \mathbf{c 1 5 t - c 1 7 t}}$ \\
\hline Case 20 & $\mathbf{W}_{\mathbf{c 1 4 t}}=(0.8,0.9,1),{ }^{1} \mathbf{W}_{\mathbf{c 1 t - c 1 3 t}, \mathbf{c 1 5 t - c 1 7 t}}$ \\
\hline Case 21 & $\mathbf{W}_{\mathbf{c 1 t}, \mathbf{c 1 3 t}}=(0,0.533,1), \mathbf{W}_{\mathbf{c 1 7 t}}=(0.8,0.9,1),{ }^{1} \mathbf{W}_{\mathbf{c 2 t - c 1 2 t}, \mathbf{c 1 4 t - c 1 6 t}}$ \\
\hline Case 22 & $\begin{array}{l}\mathbf{W}_{\mathbf{c 3 t}, \mathbf{c 1 4 t}}=(0.2,0.6,1), \mathbf{W}_{\mathbf{c 1 6 t}}=(0.6,0.867,1),{ }^{1} \mathbf{W}_{\mathbf{c 1 t - c 2 t}, \mathbf{c 4 t}-\mathbf{c 1 3 t}, \mathbf{c 1 5 t}}, \\
\mathbf{c 1 7 t}\end{array}$ \\
\hline
\end{tabular}

\footnotetext{
${ }^{1}$ same as in table 4
} 
Table 16: Results of sensitivity analysis

\begin{tabular}{|c|c|c|c|c|c|c|c|c|c|c|c|c|c|}
\hline \multirow[t]{2}{*}{ Case } & \multicolumn{12}{|c|}{ Alternatives } & \multirow[t]{2}{*}{ Ranking } \\
\hline & A1 & A2 & A3 & A4 & A5 & A6 & A7 & A8 & A9 & A10 & A11 & A12 & \\
\hline Case 1 & 0.228 & 0.397 & 0.613 & 0.588 & 0.618 & 0.303 & 0.436 & 0.328 & 0.363 & 0.616 & 0.518 & 0.59 & $\begin{array}{l}\mathrm{A} 5>\mathrm{A} 10>\mathrm{A} 3>\mathrm{A} 12>\mathrm{A} 4>\mathrm{A} 11>\mathrm{A} 7 \\
>\mathrm{A} 2>\mathrm{A} 9>\mathrm{A} 8>\mathrm{A} 6>\mathrm{A} 1\end{array}$ \\
\hline Case 2 & 0.229 & 0.398 & 0.616 & 0.593 & 0.623 & 0.302 & 0.439 & 0.327 & 0.364 & 0.62 & 0.521 & 0.595 & $\begin{array}{l}\mathrm{A} 5>\mathrm{A} 10>\mathrm{A} 3>\mathrm{A} 12>\mathrm{A} 4>\mathrm{A} 11>\mathrm{A} 7 \\
>\mathrm{A} 2>\mathrm{A} 9>\mathrm{A} 8>\mathrm{A} 6>\mathrm{A} 1\end{array}$ \\
\hline Case 3 & 0.232 & 0.397 & 0.616 & 0.595 & 0.624 & 0.3 & 0.442 & 0.324 & 0.363 & 0.621 & 0.522 & 0.597 & $\begin{array}{l}\mathrm{A} 5>\mathrm{A} 10>\mathrm{A} 3>\mathrm{A} 12>\mathrm{A} 4>\mathrm{A} 11>\mathrm{A} 7 \\
>\mathrm{A} 2>\mathrm{A} 9>\mathrm{A} 8>\mathrm{A} 6>\mathrm{A} 1\end{array}$ \\
\hline Case 4 & 0.233 & 0.396 & 0.617 & 0.599 & 0.628 & 0.298 & 0.445 & 0.322 & 0.363 & 0.624 & 0.525 & 0.601 & $\begin{array}{l}\mathrm{A} 5>\mathrm{A} 10>\mathrm{A} 3>\mathrm{A} 12>\mathrm{A} 4>\mathrm{A} 11>\mathrm{A} 7 \\
>\mathrm{A} 2>\mathrm{A} 9>\mathrm{A} 8>\mathrm{A} 6>\mathrm{A} 1\end{array}$ \\
\hline Case 5 & 0.234 & 0.396 & 0.62 & 0.604 & 0.634 & 0.298 & 0.448 & 0.322 & 0.364 & 0.628 & 0.528 & 0.606 & $\begin{array}{l}\mathrm{A} 5>\mathrm{A} 10>\mathrm{A} 3>\mathrm{A} 12>\mathrm{A} 4>\mathrm{A} 11>\mathrm{A} 7 \\
>\mathrm{A} 2>\mathrm{A} 9>\mathrm{A} 8>\mathrm{A} 6>\mathrm{A} 1\end{array}$ \\
\hline Case 6 & 0.236 & 0.381 & 0.604 & 0.597 & 0.618 & 0.303 & 0.436 & 0.314 & 0.357 & 0.612 & 0.528 & 0.599 & $\begin{array}{l}\mathrm{A} 5>\mathrm{A} 10>\mathrm{A} 3>\mathrm{A} 12>\mathrm{A} 4>\mathrm{A} 11>\mathrm{A} 7 \\
>\mathrm{A} 2>\mathrm{A} 9>\mathrm{A} 8>\mathrm{A} 6>\mathrm{A} 1\end{array}$ \\
\hline Case 7 & 0.235 & 0.385 & 0.609 & 0.6 & 0.623 & 0.303 & 0.439 & 0.316 & 0.359 & 0.617 & 0.529 & 0.602 & $\begin{array}{l}\mathrm{A} 5>\mathrm{A} 10>\mathrm{A} 3>\mathrm{A} 12>\mathrm{A} 4>\mathrm{A} 11>\mathrm{A} 7 \\
>\mathrm{A} 2>\mathrm{A} 9>\mathrm{A} 8>\mathrm{A} 6>\mathrm{A} 1\end{array}$ \\
\hline Case 8 & 0.234 & 0.389 & 0.611 & 0.6 & 0.624 & 0.3 & 0.442 & 0.319 & 0.361 & 0.619 & 0.527 & 0.602 & $\begin{array}{l}\mathrm{A} 5>\mathrm{A} 10>\mathrm{A} 3>\mathrm{A} 12>\mathrm{A} 4>\mathrm{A} 11>\mathrm{A} 7 \\
>\mathrm{A} 2>\mathrm{A} 9>\mathrm{A} 8>\mathrm{A} 6>\mathrm{A} 1\end{array}$ \\
\hline Case 9 & 0.233 & 0.393 & 0.615 & 0.601 & 0.628 & 0.298 & 0.445 & 0.321 & 0.363 & 0.623 & 0.527 & 0.603 & $\begin{array}{l}\mathrm{A} 5>\mathrm{A} 10>\mathrm{A} 3>\mathrm{A} 12>\mathrm{A} 4>\mathrm{A} 11>\mathrm{A} 7 \\
>\mathrm{A} 2>\mathrm{A} 9>\mathrm{A} 8>\mathrm{A} 6>\mathrm{A} 1\end{array}$ \\
\hline Case 10 & 0.234 & 0.396 & 0.62 & 0.604 & 0.634 & 0.298 & 0.448 & 0.322 & 0.364 & 0.628 & 0.528 & 0.606 & $\begin{array}{l}\mathrm{A} 5>\mathrm{A} 10>\mathrm{A} 3>\mathrm{A} 12>\mathrm{A} 4>\mathrm{A} 11>\mathrm{A} 7 \\
>\mathrm{A} 2>\mathrm{A} 9>\mathrm{A} 8>\mathrm{A} 6>\mathrm{A} 1\end{array}$ \\
\hline Case 11 & 0.24 & 0.377 & 0.609 & 0.592 & 0.632 & 0.289 & 0.438 & 0.319 & 0.374 & 0.617 & 0.514 & 0.602 & $\begin{array}{l}\mathrm{A} 5>\mathrm{A} 10>\mathrm{A} 3>\mathrm{A} 12>\mathrm{A} 4>\mathrm{A} 11>\mathrm{A} 7 \\
>\mathrm{A} 2>\mathrm{A} 9>\mathrm{A} 8>\mathrm{A} 6>\mathrm{A} 1\end{array}$ \\
\hline Case 12 & 0.239 & 0.383 & 0.614 & 0.597 & 0.634 & 0.291 & 0.441 & 0.32 & 0.372 & 0.622 & 0.519 & 0.604 & $\begin{array}{l}\mathrm{A} 5>\mathrm{A} 10>\mathrm{A} 3>\mathrm{A} 12>\mathrm{A} 4>\mathrm{A} 11>\mathrm{A} 7 \\
>\mathrm{A} 2>\mathrm{A} 9>\mathrm{A} 8>\mathrm{A} 6>\mathrm{A} 1\end{array}$ \\
\hline Case 13 & 0.236 & 0.389 & 0.616 & 0.6 & 0.633 & 0.295 & 0.444 & 0.321 & 0.367 & 0.624 & 0.522 & 0.604 & $\begin{array}{l}\mathrm{A} 5>\mathrm{A} 10>\mathrm{A} 3>\mathrm{A} 12>\mathrm{A} 4>\mathrm{A} 11>\mathrm{A} 7 \\
>\mathrm{A} 2>\mathrm{A} 9>\mathrm{A} 8>\mathrm{A} 6>\mathrm{A} 1\end{array}$ \\
\hline Case 14 & 0.234 & 0.395 & 0.619 & 0.603 & 0.633 & 0.298 & 0.448 & 0.322 & 0.364 & 0.627 & 0.527 & 0.606 & $\begin{array}{l}\mathrm{A} 5>\mathrm{A} 10>\mathrm{A} 3>\mathrm{A} 12>\mathrm{A} 4>\mathrm{A} 11>\mathrm{A} 7 \\
>\mathrm{A} 2>\mathrm{A} 9>\mathrm{A} 8>\mathrm{A} 6>\mathrm{A} 1\end{array}$ \\
\hline Case 15 & 0.234 & 0.401 & 0.625 & 0.609 & 0.635 & 0.299 & 0.451 & 0.323 & 0.364 & 0.633 & 0.532 & 0.609 & $\begin{array}{l}\mathrm{A} 5>\mathrm{A} 10>\mathrm{A} 3>\mathrm{A} 4>\mathrm{A} 12>\mathrm{A} 11>\mathrm{A} 7 \\
>\mathrm{A} 2>\mathrm{A} 9>\mathrm{A} 8>\mathrm{A} 6>\mathrm{A} 1\end{array}$ \\
\hline Case 16 & 0.24 & 0.377 & 0.609 & 0.592 & 0.622 & 0.29 & 0.446 & 0.315 & 0.358 & 0.617 & 0.514 & 0.602 & $\begin{array}{l}\mathrm{A} 5>\mathrm{A} 10>\mathrm{A} 3>\mathrm{A} 12>\mathrm{A} 4>\mathrm{A} 11>\mathrm{A} 7 \\
>\mathrm{A} 2>\mathrm{A} 9>\mathrm{A} 8>\mathrm{A} 6>\mathrm{A} 1\end{array}$ \\
\hline Case 17 & 0.239 & 0.383 & 0.614 & 0.597 & 0.627 & 0.292 & 0.447 & 0.317 & 0.359 & 0.622 & 0.519 & 0.604 & $\begin{array}{l}\mathrm{A} 5>\mathrm{A} 10>\mathrm{A} 3>\mathrm{A} 12>\mathrm{A} 4>\mathrm{A} 11>\mathrm{A} 7 \\
>\mathrm{A} 2>\mathrm{A} 9>\mathrm{A} 8>\mathrm{A} 6>\mathrm{A} 1\end{array}$ \\
\hline
\end{tabular}




\begin{tabular}{|c|c|c|c|c|c|c|c|c|c|c|c|c|c|}
\hline Case 18 & 0.236 & 0.389 & 0.616 & 0.6 & 0.629 & 0.295 & 0.447 & 0.319 & 0.361 & 0.624 & 0.522 & 0.604 & $\begin{array}{l}\mathrm{A} 5>\mathrm{A} 10>\mathrm{A} 3>\mathrm{A} 12>\mathrm{A} 4>\mathrm{A} 11>\mathrm{A} 7 \\
>\mathrm{A} 2>\mathrm{A} 9>\mathrm{A} 8>\mathrm{A} 6>\mathrm{A} 1\end{array}$ \\
\hline Case 19 & 0.234 & 0.395 & 0.619 & 0.603 & 0.633 & 0.298 & 0.448 & 0.322 & 0.363 & 0.627 & 0.527 & 0.606 & $\begin{array}{l}\mathrm{A} 5>\mathrm{A} 10>\mathrm{A} 3>\mathrm{A} 12>\mathrm{A} 4>\mathrm{A} 11>\mathrm{A} 7 \\
>\mathrm{A} 2>\mathrm{A} 9>\mathrm{A} 8>\mathrm{A} 6>\mathrm{A} 1\end{array}$ \\
\hline Case 20 & 0.234 & 0.401 & 0.625 & 0.609 & 0.638 & 0.299 & 0.449 & 0.323 & 0.364 & 0.633 & 0.532 & 0.609 & $\begin{array}{l}\mathrm{A} 5>\mathrm{A} 10>\mathrm{A} 3>\mathrm{A} 4>\mathrm{A} 12>\mathrm{A} 11>\mathrm{A} 7 \\
>\mathrm{A} 2>\mathrm{A} 9>\mathrm{A} 8>\mathrm{A} 6>\mathrm{A} 1\end{array}$ \\
\hline Case 21 & 0.238 & 0.403 & 0.608 & 0.592 & 0.613 & 0.299 & 0.442 & 0.325 & 0.366 & 0.612 & 0.532 & 0.583 & $\begin{array}{l}\mathrm{A} 5>\mathrm{A} 10>\mathrm{A} 3>\mathrm{A} 4>\mathrm{A} 12>\mathrm{A} 11>\mathrm{A} 7 \\
>\mathrm{A} 2>\mathrm{A} 9>\mathrm{A} 8>\mathrm{A} 6>\mathrm{A} 1\end{array}$ \\
\hline Case 22 & 0.233 & 0.382 & 0.606 & 0.59 & 0.626 & 0.294 & 0.443 & 0.318 & 0.364 & 0.614 & 0.514 & 0.595 & $\begin{array}{l}\mathrm{A} 5>\mathrm{A} 10>\mathrm{A} 3>\mathrm{A} 12>\mathrm{A} 4>\mathrm{A} 11>\mathrm{A} 7 \\
>\mathrm{A} 2>\mathrm{A} 9>\mathrm{A} 8>\mathrm{A} 6>\mathrm{A} 1\end{array}$ \\
\hline
\end{tabular}

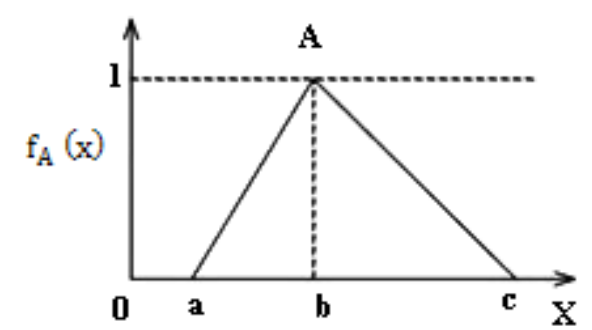

Figure 2: Membership function of triangular fuzzy number A

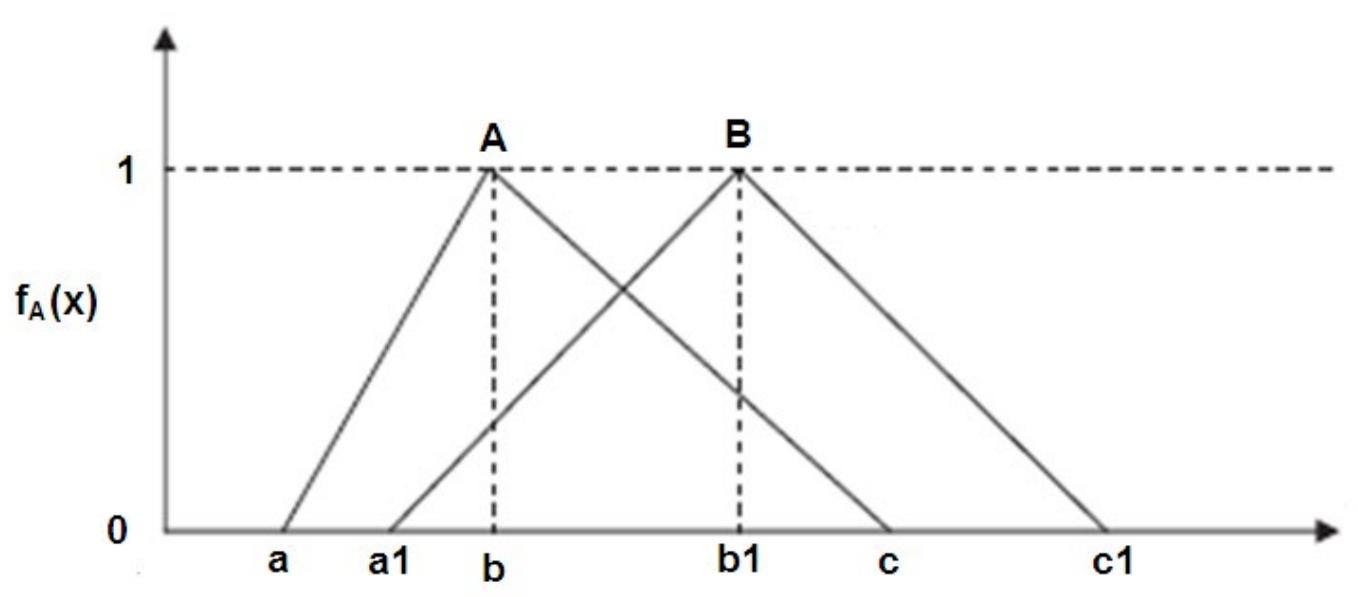

Figure 3: Two triangular fuzzy numbers 
National Policy on Solid Waste
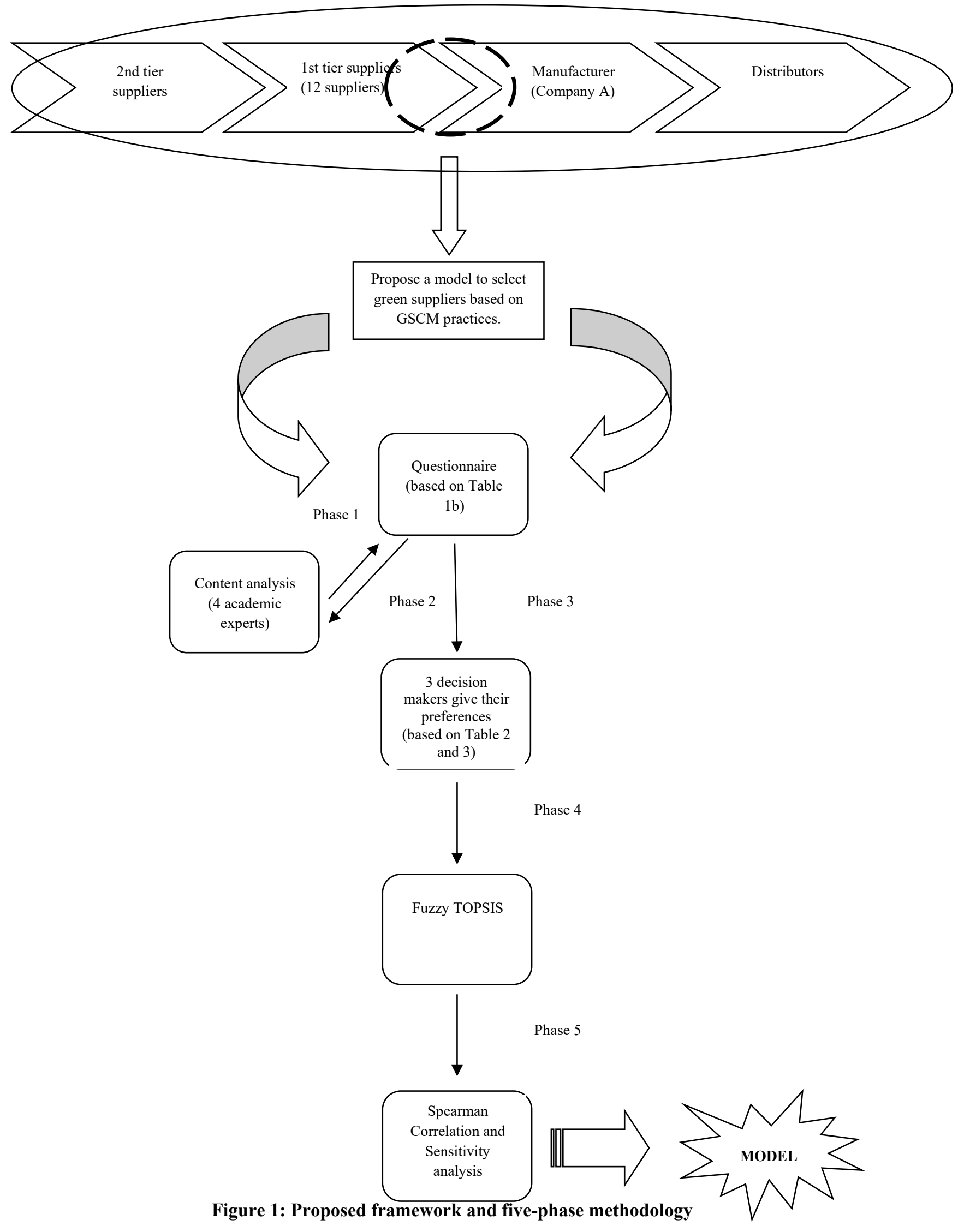


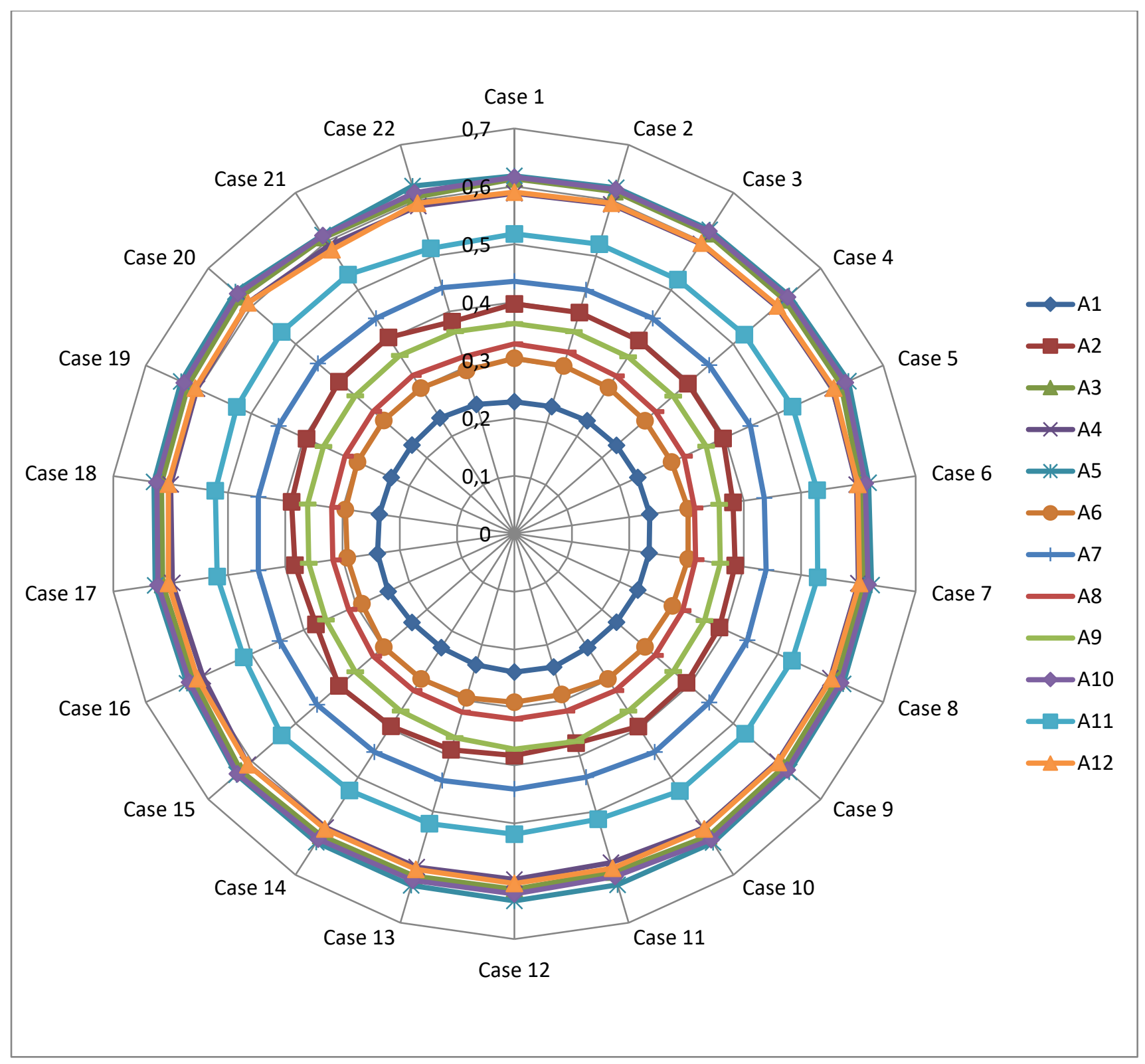

Figure 4: Results of sensitivity analysis 